\title{
LEVEL II SCOUR ANALYSIS FOR BRIDGE 18 (SHEFTH00410018) on TOWN HIGHWAY 41, crossing MILLERS RUN, SHEFFIELD, VERMONT
}

Open-File Report 97-772

Prepared in cooperation with

VERMONT AGENCY OF TRANSPORTATION

and

FEDERAL HIGHWAY ADMINISTRATION

U.S. Department of the Interior

U.S. Geological Survey

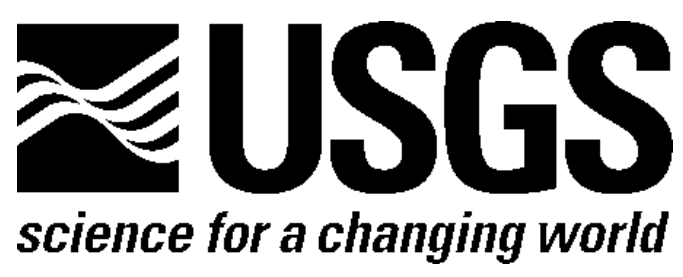




\section{LEVEL II SCOUR ANALYSIS FOR BRIDGE 18 (SHEFTH00410018) on TOWN HIGHWAY 41, crossing MILLERS RUN, SHEFFIELD, VERMONT \\ By EMILY C. WILD and ERICK M. BOEHMLER \\ U.S. Geological Survey Open-File Report 97-772}

Prepared in cooperation with

VERMONT AGENCY OF TRANSPORTATION

and

FEDERAL HIGHWAY ADMINISTRATION 


\title{
U.S. DEPARTMENT OF THE INTERIOR BRUCE BABBITT, Secretary
}

\author{
U.S. GEOLOGICAL SURVEY \\ Mark Schaefer, Acting Director
}

For additional information write to:

District Chief

U.S. Geological Survey 361 Commerce Way

Pembroke, NH 03275-3718
Copies of this report may be purchased from:

U.S. Geological Survey

Branch of Information Services

Open-File Reports Unit

Box 25286

Denver, CO 80225-0286 


\section{CONTENTS}

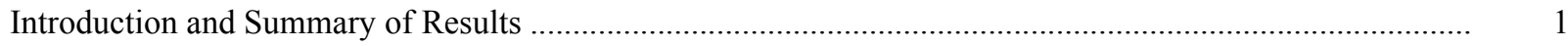

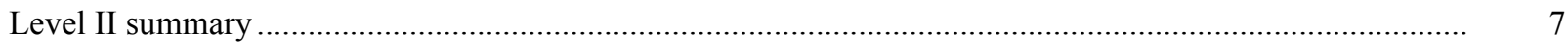

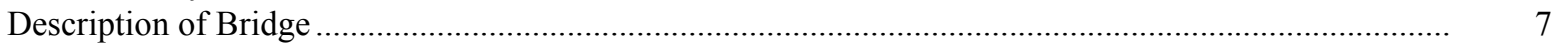

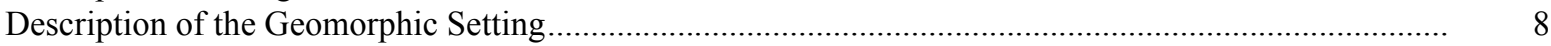

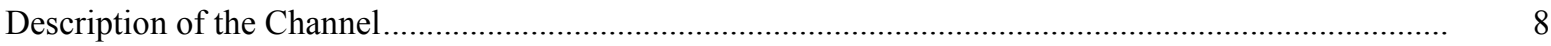

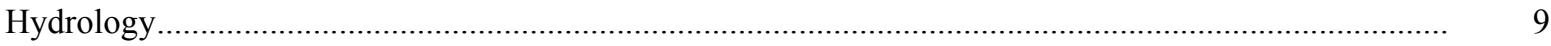

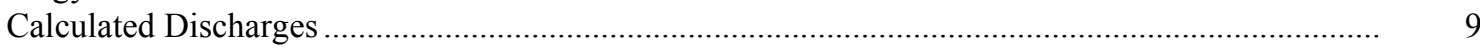

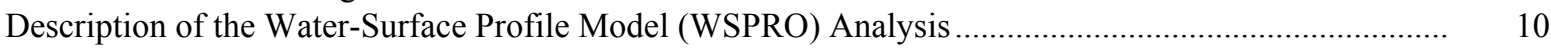

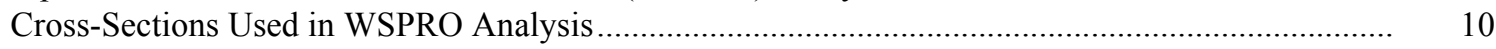

Data and Assumptions Used in WSPRO Model ...................................................................... 11

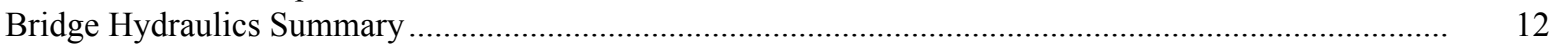

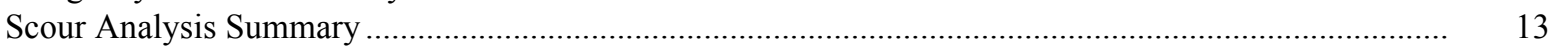

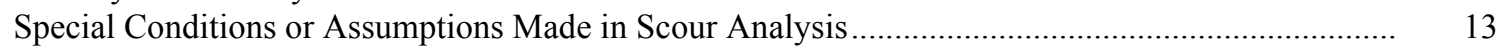

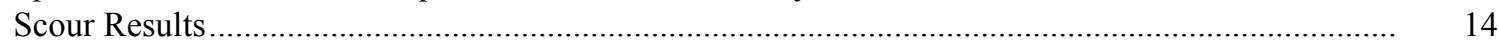

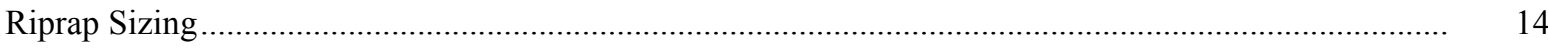

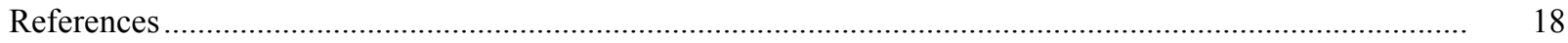

Appendixes:

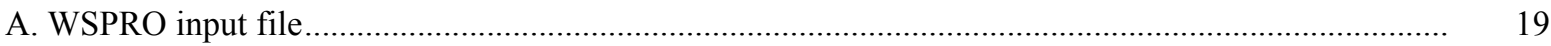

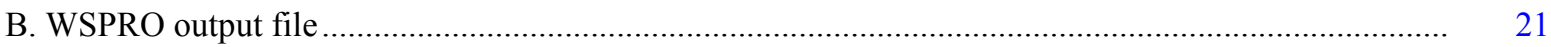

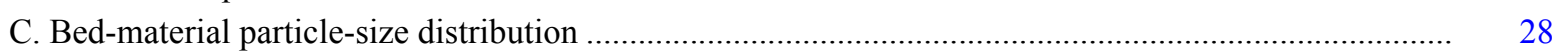

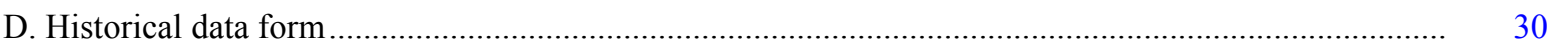

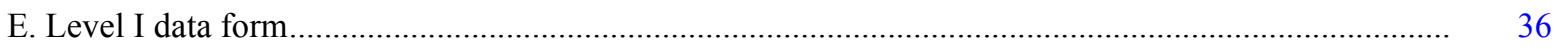

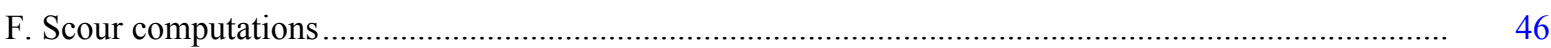

\section{FIGURES}

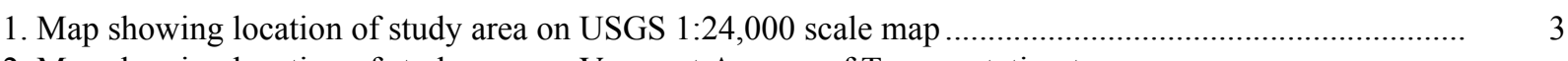

2. Map showing location of study area on Vermont Agency of Transportation town
highway map

3. Structure SHEFTH00410018 viewed from upstream (August 1, 1995) ................................................. 5

4. Downstream channel viewed from structure SHEFTH00410018 (August 1, 1995).............................. 5

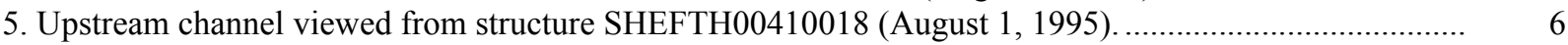

6. Structure SHEFTH00410018 viewed from downstream (August 1, 1995)........................................ 6

7. Water-surface profiles for the 100- and 500-year discharges at structure

SHEFTH00410018 on Town Highway 41, crossing Millers Run,

Sheffield, Vermont.

8. Scour elevations for the 100- and 500-year discharges at structure

SHEFTH00410018 on Town Highway 41, crossing Millers Run,

Sheffield Vermont.

\section{TABLES}

1. Remaining footing/pile depth at abutments for the 100-year discharge at structure

SHEFTH00410018 on Town Highway 41, crossing Millers Run,

Sheffield, Vermont.

2. Remaining footing/pile depth at abutments for the 500-year discharge at structure

SHEFTH00410018 on Town Highway 41, crossing Millers Run,

Sheffield, Vermont. 


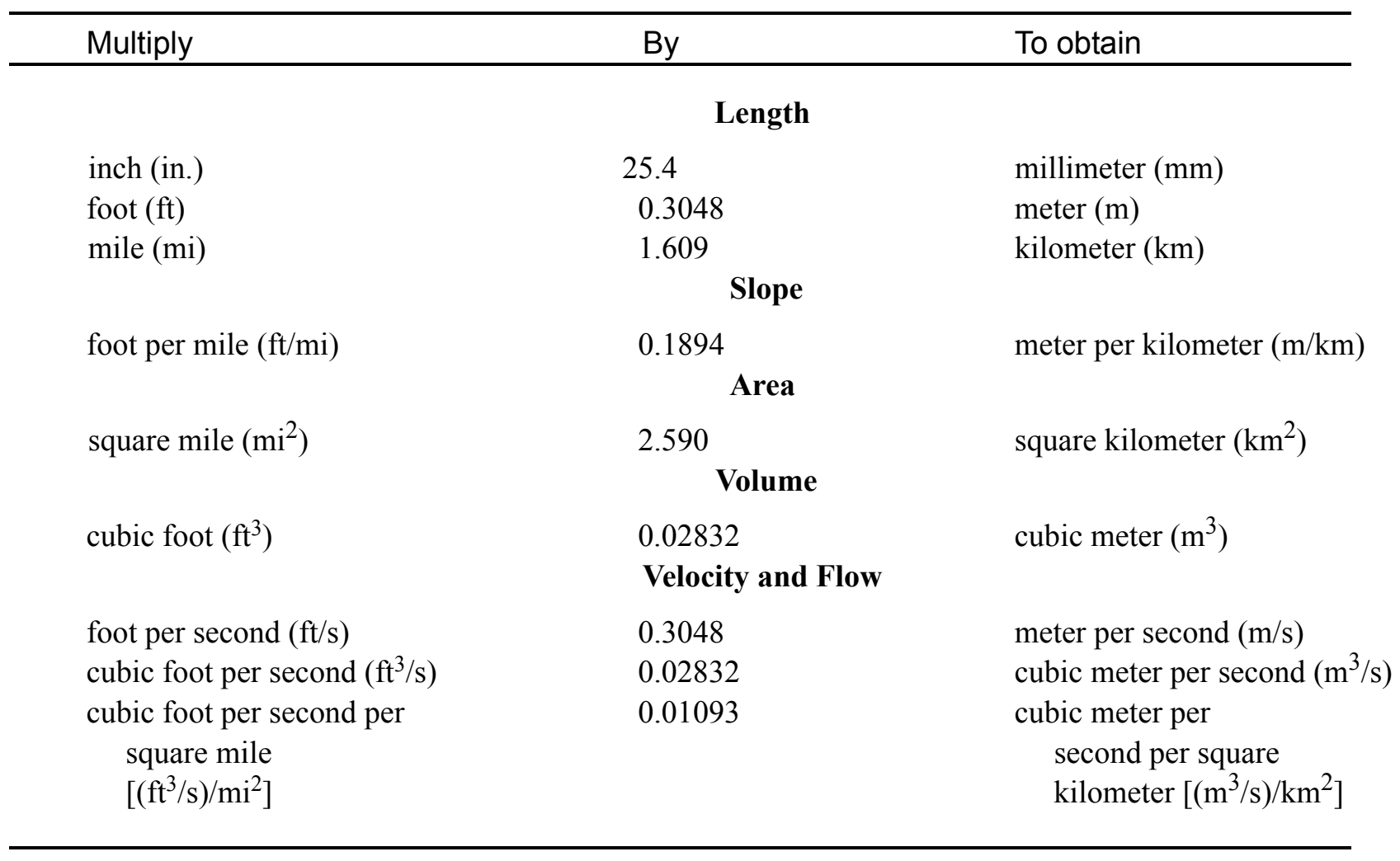

\section{OTHER ABBREVIATIONS}

$\begin{array}{lrlr}\mathrm{BF} & \text { bank full } & \text { LWW } & \text { left wingwall } \\ \mathrm{cfs} & \text { cubic feet per second } & \text { MC } & \text { main channel } \\ \mathrm{D}_{50} & \text { median diameter of bed material } & \text { RAB } & \text { right abutment } \\ \mathrm{DS} & \text { downstream } & \text { RABUT } & \text { face of right abutment } \\ \mathrm{elev} & \text { elevation } & \text { RB } & \text { right bank } \\ \mathrm{f} / \mathrm{p} & \text { flood plain } & \text { ROB } & \text { right overbank } \\ \mathrm{ft}^{2} & \text { square feet } & \text { RWW } & \text { right wingwall } \\ \mathrm{ft} / \mathrm{ft} & \text { feet per foot } & \text { TH } & \text { town highway } \\ \mathrm{JCT} & \text { junction } & \text { UB } & \text { under bridge } \\ \mathrm{LAB} & \text { left abutment } & \text { US } & \text { upstream } \\ \mathrm{LABUT} & \text { face of left abutment } & \text { USGS } & \text { United States Geological Survey } \\ \mathrm{LB} & \text { left bank } & \text { VTAOT Vermont Agency of Transportation } \\ \mathrm{LOB} & \text { left overbank } & \text { WSPRO } & \text { water-surface profile model }\end{array}$

In this report, the words "right" and "left" refer to directions that would be reported by an observer facing downstream. Sea level: In this report, "sea level" refers to the National Geodetic Vertical Datum of 1929-- a geodetic datum derived from a general adjustment of the first-order level nets of the United States and Canada, formerly called Sea Level Datum of 1929.

In the appendices, the above abbreviations may be combined. For example, USLB would represent upstream left bank. 


\title{
LEVEL II SCOUR ANALYSIS FOR BRIDGE 18 (SHEFTH00410018) ON TOWN HIGHWAY 41, CROSSING MILLERS RUN, SHEFFIELD, VERMONT
}

\author{
By Emily C. Wild and Erick M. Boehmler
}

\section{INTRODUCTION AND SUMMARY OF RESULTS}

This report provides the results of a detailed Level II analysis of scour potential at structure SHEFTH00410018 on Town Highway 41 crossing Millers Run, Sheffield, Vermont (figures 1-8). A Level II study is a basic engineering analysis of the site, including a quantitative analysis of stream stability and scour (U.S. Department of Transportation, 1993). Results of a Level I scour investigation also are included in Appendix E of this report. A Level I investigation provides a qualitative geomorphic characterization of the study site. Information on the bridge, gleaned from Vermont Agency of Transportation (VTAOT) files, was compiled prior to conducting Level I and Level II analyses and is found in Appendix D.

The site is in the White Mountain section of the New England physiographic province in northeastern Vermont. The 16.2- $\mathrm{mi}^{2}$ drainage area is in a predominantly rural and forested basin. In the vicinity of the study site, the surface cover is grass upstream and downstream of the bridge while the immediate banks have dense woody vegetation.

In the study area, Millers Run has an incised, straight channel with a slope of approximately $0.01 \mathrm{ft} / \mathrm{ft}$, an average channel top width of $50 \mathrm{ft}$ and an average bank height of $6 \mathrm{ft}$. The channel bed material ranges from sand to boulder with a median grain size $\left(\mathrm{D}_{50}\right)$ of 50.9 $\mathrm{mm}(0.167 \mathrm{ft})$. The geomorphic assessment at the time of the Level I and Level II site visit on August 1, 1995, indicated that the reach was laterally unstable, which is evident in the moderate to severe fluvial erosion in the upstream reach.

The Town Highway 41 crossing of the Millers Run is a 30-ft-long, one-lane bridge consisting of a 28-foot steel-stringer span (Vermont Agency of Transportation, written communication, March 28, 1995). The opening length of the structure parallel to the bridge face is $22.2 \mathrm{ft}$. The bridge is supported by vertical, concrete abutments with wingwalls. The channel is skewed approximately 20 degrees to the opening. The computed opening-skewto-roadway is 5 degrees, while it is zero degrees in the historical form. 
A scour hole $1.0 \mathrm{ft}$ deeper than the mean thalweg depth was observed along the left abutment during the Level I assessment. The scour protection measure at the site includes type- 1 stone fill (less than 12 inches diameter) along the upstream right wingwall and the upstream left wingwall. Type-2 stone fill (less than 36 inches diameter) extends along the downstream end of the downstream left wingwall, the upstream right bank and the downstream left bank. The downstream right bank is protected by type- 2 stone fill and a stone masonry wall. Additional details describing conditions at the site are included in the Level II Summary and Appendices D and E.

Scour depths and recommended rock rip-rap sizes were computed using the general guidelines described in Hydraulic Engineering Circular 18 (Richardson and others, 1995) for the 100- and 500-year discharges. In addition, the incipient roadway-overtopping discharge is determined and analyzed as another potential worst-case scour scenario. Total scour at a highway crossing is comprised of three components: 1) long-term streambed degradation; 2) contraction scour (due to accelerated flow caused by a reduction in flow area at a bridge) and; 3 ) local scour (caused by accelerated flow around piers and abutments). Total scour is the sum of the three components. Equations are available to compute depths for contraction and local scour and a summary of the results of these computations follows.

Contraction scour for all modelled flows ranged from 0.2 to $1.8 \mathrm{ft}$. The worst-case contraction scour occurred at the 100-year and 500-year discharges. Left abutment scour ranged from 14.1 to $16.4 \mathrm{ft}$. The worst-case left abutment scour occurred at the 500-year discharge. Right abutment scour ranged from 6.9 to $9.3 \mathrm{ft}$. The worst-case right abutment scour occurred at the incipient roadway-overtopping discharge. Additional information on scour depths and depths to armoring are included in the section titled "Scour Results". Scoured-streambed elevations, based on the calculated scour depths, are presented in tables 1 and 2. A cross-section of the scour computed at the bridge is presented in figure 8. Scour depths were calculated assuming an infinite depth of erosive material and a homogeneous particle-size distribution.

It is generally accepted that the Froehlich equation (abutment scour) gives "excessively conservative estimates of scour depths" (Richardson and others, 1995, p. 47). Usually, computed scour depths are evaluated in combination with other information including (but not limited to) historical performance during flood events, the geomorphic stability assessment, existing scour protection measures, and the results of the hydraulic analyses. Therefore, scour depths adopted by VTAOT may differ from the computed values documented herein. 


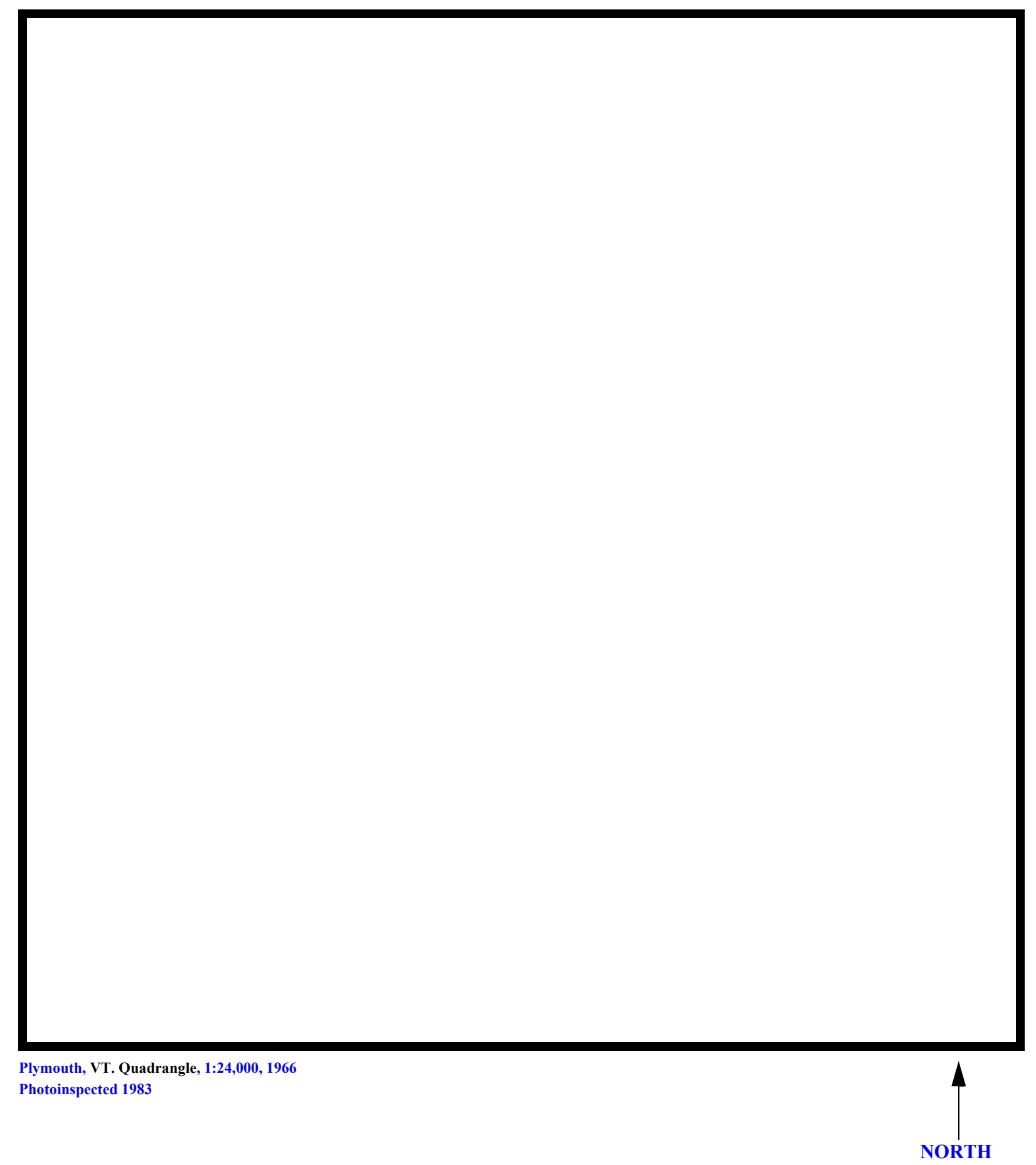

Figure 1. Location of study area on USGS 1:24,000 scale map. 
Figure 2. Location of study area on Vermont Agency of Transportation town highway map. 

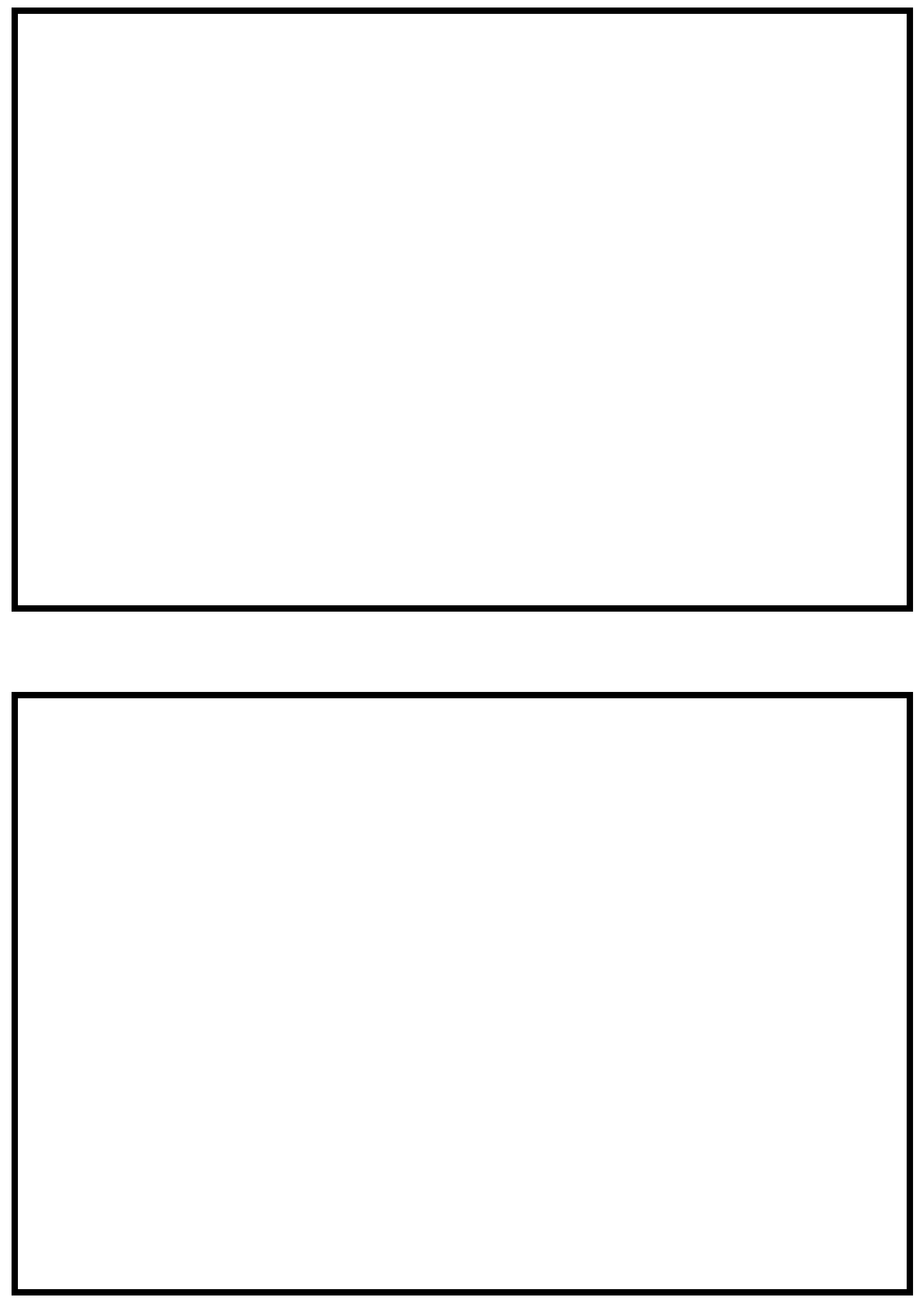

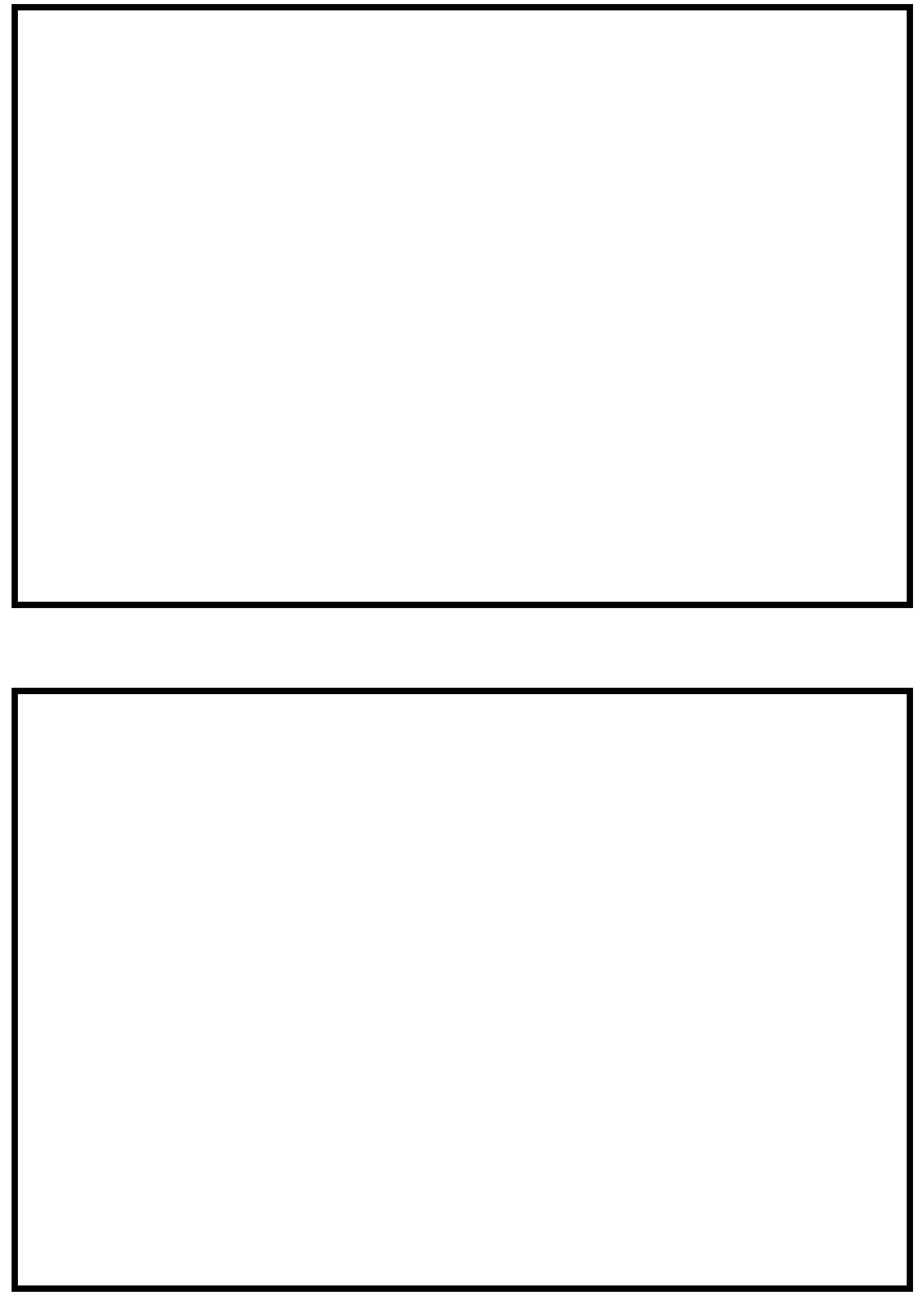


\section{LEVEL II SUMMARY}

\begin{tabular}{llllll} 
Structure Number & \multicolumn{2}{c}{ SHEFTH00410018 } & \multirow{2}{c}{ Millers Run } \\
Stream & & & \\
County & Caledonia & Road & TH41 & District & 7
\end{tabular}

\section{Description of Bridge}

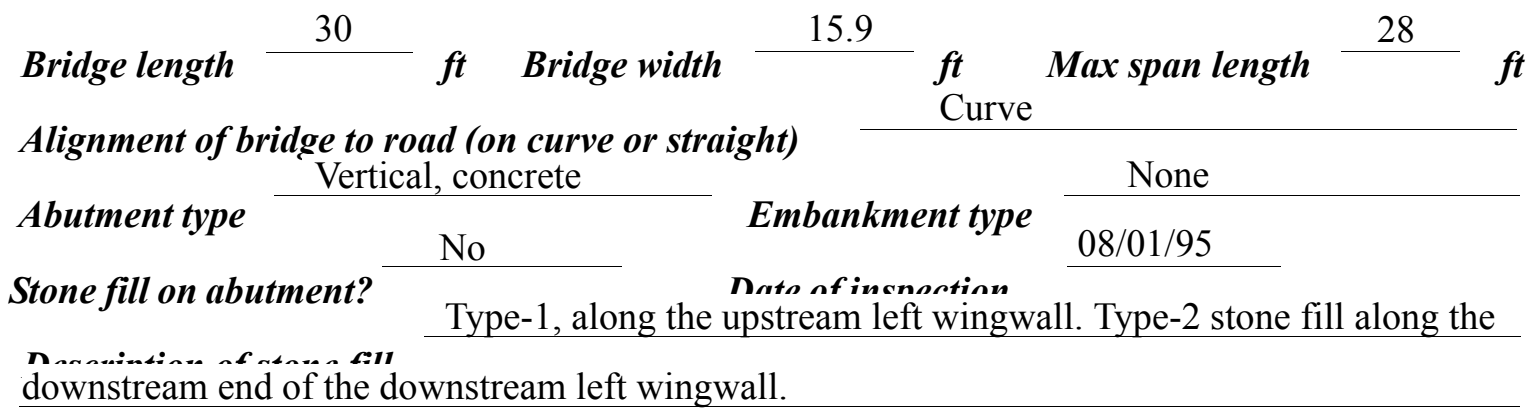

Abutments and wingwalls are concrete. There is a one to one and a half foot (deep) scour hole in front of the upstream left wingwall and along the left abutment.

Yes 20

Is bridge skewed to flood flow according to No ' survey? Angle

Debris accumulation on bridge at time of Level I or Level II site visit:

\begin{tabular}{|c|c|c|c|}
\hline & $\begin{array}{c}\text { Date of incnortion } \\
08 / 01 / 95 \\
\end{array}$ & $\begin{array}{l}\text { Percent of almanol } \\
\text { blocked inortzontatly }\end{array}$ & $\begin{array}{l}\text { Percent of } 0 \\
\text { blocked verticatty }\end{array}$ \\
\hline & $08 / 01 / 95$ & 0 & 0 \\
\hline
\end{tabular}

Level II Moderate. A lot of vegetation is present along the channel banks.

None, 08/01/95.

Potential for debris

Doscriho any, foaturos noar ar at tho hridoo that mav, affort flou, (includo ahsorvation dato) 


\section{Description of the Geomorphic Setting}

General topography The channel is located within a narrow flood plain with steep valley walls on both sides.

Geomorphic conditions at bridge site: downstream (DS), upstream (US)

Date of inspection $\quad \underline{08 / 01 / 95}$

DS left: $\quad$ Steep channel bank to a moderately sloped overbank.

DS right: $\quad$ Steep channel bank to a narrow flood plain.

US left: $\quad$ Steep channel bank to a moderately sloped overbank.

US right: Steep channel bank to a narrow flood plain.

\section{Description of the Channel}

\begin{tabular}{|c|c|c|c|c|}
\hline \multirow[b]{2}{*}{ Average top width } & 50 & \multirow[b]{2}{*}{ Average depth } & 6 & \multirow[b]{2}{*}{$f$} \\
\hline & $\stackrel{\boldsymbol{f t}}{\text { Gravel / Cobbles }}$ & & Silt/ Sand & \\
\hline Predominant bed mo & & Bank material & Straight and la & terally \\
\hline
\end{tabular}

unstable with semi-alluvial boundaries and a narrow flood plain.

Vegetative co 1 Trees and brush along immediate bank, while overbank is grass.

DS left: $\quad$ Trees and brush along immediate bank, while overbank is grass.

DS right: $\quad$ Trees and brush along immediate bank., while overbank is grass.

US left: $\quad$ Trees and brush along immediate bank, while overbank is grass.

US right: $\quad$ Yes

Do banks appear stable? -

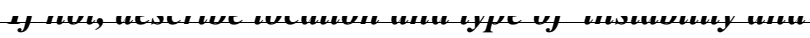

date of observatton.

$01 / 95$ noted no obstructions in the channel.

Describe any obstructions in channel and date of observation. 


\title{
Hydrology
}

Drainage area $\frac{16.2}{m^{2}}{ }^{2}$

Percentage of drainage area in physiographic provinces: (approximate)

Physiographic province/section

New England/White Mountain
Percent of drainage area 100

Is drainage area considered rural or urban? Rural Describe any significant urbanization: There are a few houses on the upstream and downstream right overbanks.

No

Is there a USGS gage on the stream of interest?

USGS gage description

USGS gage number

Gage drainage area $\quad \mathrm{mi}^{2}$

Is there a lake/p

(n)

\section{Is there a lake/p}

(n)

(...

\begin{abstract}
$+\infty$
\end{abstract}

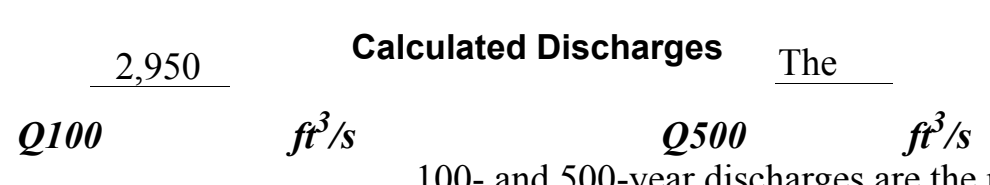

100- and 500-year discharges are the median values

selected from those based on several empirical flood frequency curves, which were extrapolated to the 500-year event (Benson, 1962; Johnson and Tasker, 1974; FHWA, 1983; Potter, 1957a\&b; Talbot, 1887). 


\section{Description of the Water-Surface Profile Model (WSPRO) Analysis}

Datum for WSPRO analysis (USGS survey, sea level, VTAOT plans)

USGS survey

Datum tie between USGS survey and VTAOT plans

None

Description of reference marks used to determine USGS datum. $\quad$ RM1 is a chiseled X on

top of the wooden bridge deck at the downstream right end (elev. $499.39 \mathrm{ft}$, arbitrary survey

datum). RM2 is a chiseled X on top of the wooden bridge deck at the upstream left end (elev.

$499.26 \mathrm{ft}$, arbitrary survey datum).

\section{Cross-Sections Used in WSPRO Analysis}

\begin{tabular}{cccl}
\hline${ }^{1}$ Cross-section & $\begin{array}{c}\text { Section } \\
\text { Reference } \\
\text { Distance } \\
\text { (SRD) } \text { in feet }\end{array}$ & $\begin{array}{c}{ }^{2} \text { Cross-section } \\
\text { development }\end{array}$ & \multicolumn{1}{c}{ Comments } \\
\hline EXITX & -28 & 1 & $\begin{array}{l}\text { Exit section } \\
\text { Downstream Full-valley } \\
\text { section (Templated from } \\
\text { EXITX) }\end{array}$ \\
FULLV & 0 & 2 & $\begin{array}{l}\text { Bridge section } \\
\text { Road Grade section }\end{array}$ \\
RDWAY & 0 & 1 & $\begin{array}{l}\text { Modelled Approach sec- } \\
\text { tion (Templated from } \\
\text { APTEM) }\end{array}$ \\
& 8 & 1 & $\begin{array}{l}\text { APTEM) } \\
\text { Approach section as sur- } \\
\text { veyed (Used as a tem- } \\
\text { plate) }\end{array}$ \\
\hline
\end{tabular}

${ }^{1}$ For location of cross-sections see plan-view sketch included with Level I field form, Appendix E.

For more detail on how cross-sections were developed see WSPRO input file. 


\section{Data and Assumptions Used in WSPRO Model}

Hydraulic analyses of the reach were done by use of the Federal Highway Administration's WSPRO step-backwater computer program (Shearman and others, 1986, and Shearman, 1990). The analyses reported herein reflect conditions existing at the site at the time of the study. Furthermore, in the development of the model it was necessary to assume no accumulation of debris or ice at the site. Results of the hydraulic model are presented in the Bridge Hydraulic Summary, Appendix B, and figure 7.

Channel roughness factors (Manning's “ $n$ ”) used in the hydraulic model were estimated using field inspections at each cross section following the general guidelines described by Arcement and Schneider (1989). Final adjustments to the values were made during the modelling of the reach. Channel " $n$ " values for the reach ranged from 0.045 to 0.055 , and overbank " $n$ " values ranged from 0.045 to 0.060 .

Normal depth at the exit section (EXITX) was assumed as the starting water surface. This depth was computed by use of the slope-conveyance method outlined in the user's manual for WSPRO (Shearman, 1990). The slope used was $0.0117 \mathrm{ft} / \mathrm{ft}$, which was estimated from the topographic map (U.S. Geological Survey, 1988).

The surveyed approach section (APTEM) was moved along the approach channel slope $(0.008 \mathrm{ft} / \mathrm{ft})$ to establish the modelled approach section (APPRO), one bridge length upstream of the upstream face as recommended by Shearman and others (1986). This location also provides a consistent method for determining scour variables. 


\section{Bridge Hydraulics Summary}

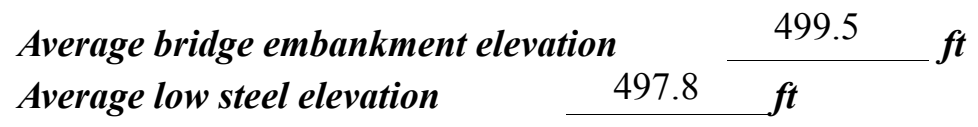

100-year discharge $\quad 2,400 \quad \mathrm{ft}^{3} / \mathrm{s}$

Water-surface elevation in bridge opening $\quad 497.9 \quad f t$

Road overtopping? ___ Y Discharge over road __ $\quad$\begin{tabular}{lll}
$\mathrm{ft}^{3} / \mathrm{s}$ \\
\hline
\end{tabular}

Area of flow in bridge opening $\quad 177 \quad \mathrm{ft}^{2}$

Average velocity in bridge opening $10.3 \mathrm{ft} / \mathrm{s}$

$\begin{array}{llll}\text { Maximum WSPRO tube velocity at bridge } & 12.4 \mathrm{ft} / \mathrm{s}\end{array}$

Water-surface elevation at Approach section with bridge 500.8

Water-surface elevation at Approach section without bridge $\quad 498.5$

Amount of backwater caused by bridge

$2.3 \quad i$

500-year discharge $\quad 2,950 \quad \mathrm{ft}^{3} / \mathrm{s}$

Water-surface elevation in bridge opening

$497.9 \boldsymbol{f t}$

Road overtopping? ___ Y Discharge over road __ 1,091 $\mathrm{ft}^{3} / \mathrm{s}$

Area of flow in bridge opening $\quad 177 \quad \mathrm{ft}^{2}$

Average velocity in bridge opening $10.3 \mathrm{ft} / \mathrm{s}$

Maximum WSPRO tube velocity at bridge 12.5 , s

Water-surface elevation at Approach section with bridge 501.1

Water-surface elevation at Approach section without bridge $\quad 498.9$

Amount of backwater caused by bridge $\quad 2.2$.t

Incipient overtopping discharge $\quad 1,490 \mathrm{ft}^{3} / \mathrm{s}$

Water-surface elevation in bridge opening $\quad 497.9 \quad$ t

Area of flow in bridge opening $\quad 177 \quad \mathrm{ft}^{2}$

Average velocity in bridge opening $\quad 8.4 \quad \mathrm{ft} / \mathrm{s}$

Maximum WSPRO tube velocity at bridge $\quad 10.2 \mathrm{ft} / \mathrm{s}$

Water-surface elevation at Approach section with bridge

Water-surface elevation at Approach section without bridge

499.4

Amount of backwater caused by bridge $\quad 1.9$, t

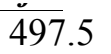




\section{Scour Analysis Summary}

\section{Special Conditions or Assumptions Made in Scour Analysis}

Scour depths were computed using the general guidelines described in Hydraulic Engineering Circular 18 (Richardson and others, 1995). Scour depths were calculated assuming an infinite depth of erosive material and a homogeneous particle-size distribution. The results of the scour analysis are presented in tables 1 and 2 and a graph of the scour depths is presented in figure 8 .

At this site, the 100-year and 500-year discharges resulted in submerged orifice flow, while the incipient roadway-overtopping discharge resulted in unsubmerged orifice flow. Contraction scour at bridges with orifice flow is best estimated by use of the Chang pressureflow scour equation (oral communication, J. Sterling Jones, October 4, 1996). Thus, contraction scour for these discharges was computed by use of the Chang equation (Richardson and others, 1995, p. 145-146). Results of this scour analysis are shown in tables 1 and 2 and figure 8. The computed streambed armoring depths suggest that armoring will not limit the depth of contraction scour.

For comparison, contraction scour for the discharges resulting in orifice flow was also computed by use of the Laursen clear-water contraction scour equation (Richardson and others, 1995, p. 32, equation 20) and the Umbrell pressure-flow equation (Richardson and others, 1995, p. 144) and presented in Appendix F. Furthermore, for the incipient roadwayovertopping discharge, which resulted in unsubmerged orifice flow, contraction scour was computed by substituting estimates for the depth of flow at the downstream bridge face in the contraction scour equations. Results with respect to these substitutions are provided in Appendix F.

Abutment scour was computed by use of the Froehlich equation (Richardson and others, 1995, p. 48, equation 28). Variables for the Froehlich equation include the Froude number of the flow approaching the embankments, the length of the embankment blocking flow, and the depth of flow approaching the embankment less any roadway overtopping. 


\section{Scour Results}

100-yr discharge 500-yr discharge

(Scour depths in feet)

Main channel

Live-bed scour

Clear-water scour

Depth to armoring

Left overbank

Right overbank

Local scour:

Abutment scour

Left abutment

Right abutment

Pier scour

Pier 1

Pier 2

Pier 3

\section{Abutments:}

Left abutment

Right abutment

Piers:

Pier 1

Pier 2

Incipient overtopping discharge
16.4

6.9-
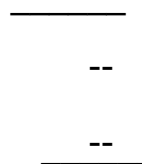

$--$

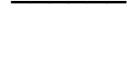

14.1

9.3-
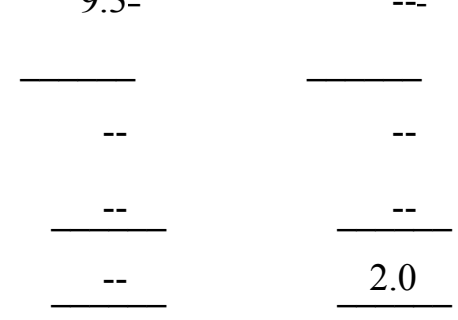

2.0

8.6

\section{Riprap Sizing}

Incipient overtopping 100-yr discharge 500-yrdischarge discharge

2.1

2.1
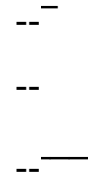
( $D_{50}$ in feet)

1.6

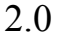

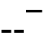

$--$

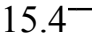




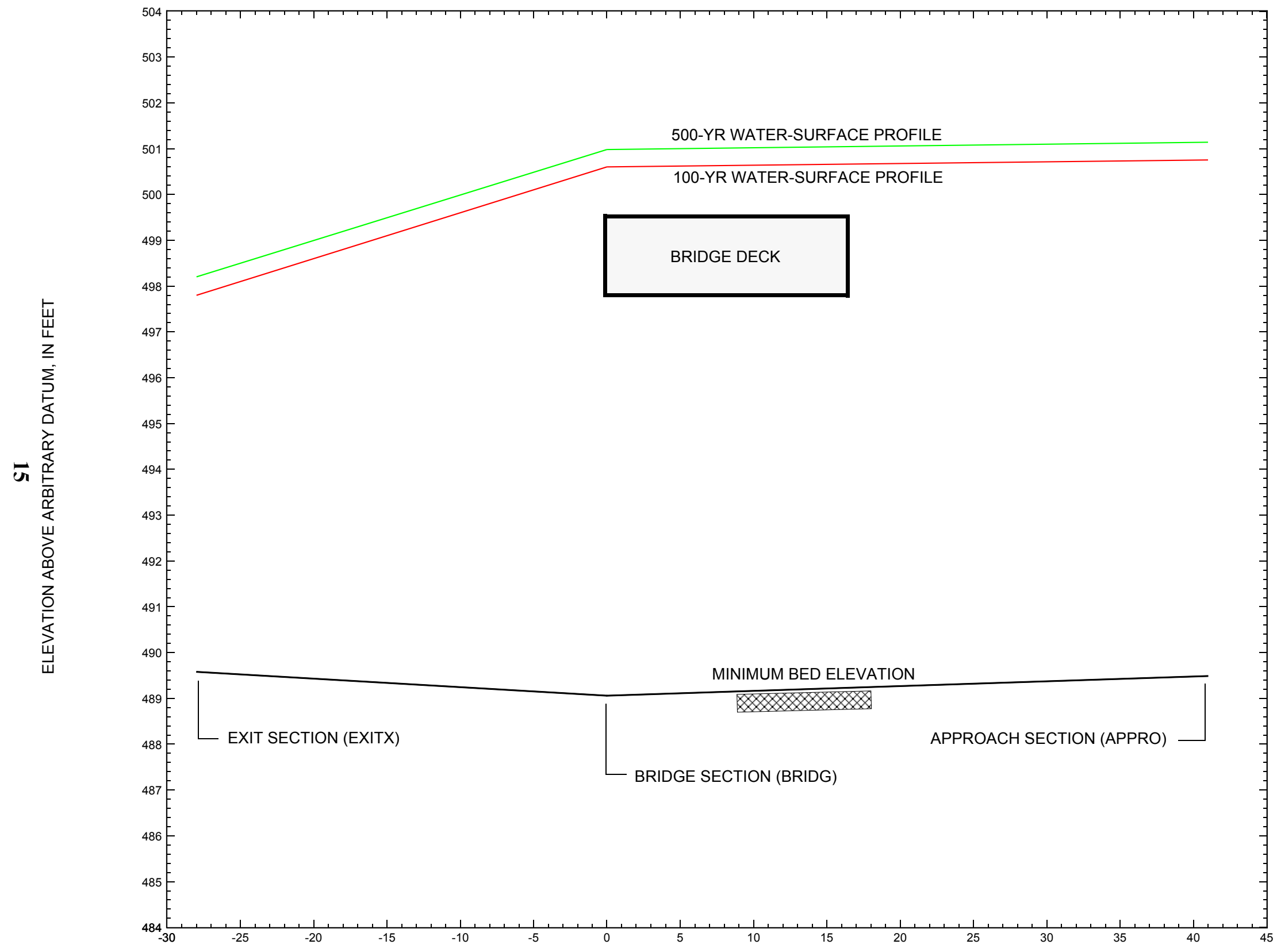

Figure 7. Water-surface profiles for the 100- and 500-yr discharges at structure SHEFTH00410018 on Town Highway 41, crossing Millers Run, Sheffield, Vermont. 


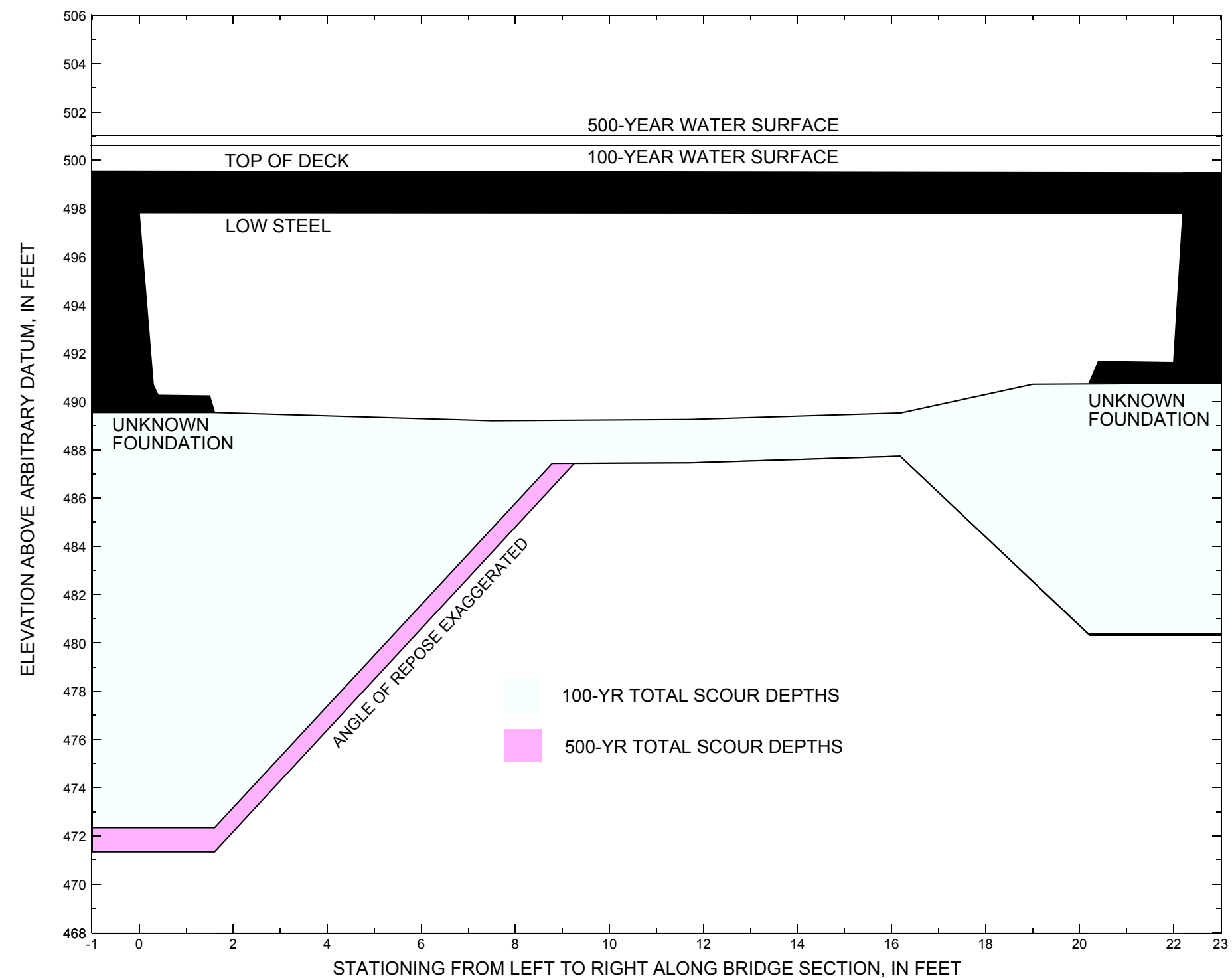

Figure 8. Scour elevations for the 100-yr and 500-yr discharges at structure SHEFTH00410018 on Town Highway 41, crossing Millers Run, Sheffield, Vermont. 
Table 1. Remaining footing/pile depth at abutments for the 100-year discharge at structure SHEFTH00410018 on Town Highway 41 , crossing Millers Run, Sheffield, Vermont.

[VTAOT, Vermont Agency of Transportation; --,no data]

\begin{tabular}{|c|c|c|c|c|c|c|c|c|c|c|c|}
\hline Description & Station $^{1}$ & $\begin{array}{l}\text { VTAOT } \\
\text { minimum } \\
\text { low-chord } \\
\text { elevation } \\
\text { (feet) }\end{array}$ & $\begin{array}{c}\text { Surveyed } \\
\text { minimum } \\
\text { low-chord } \\
\text { elevation } \\
\text { (feet) }\end{array}$ & $\begin{array}{c}\text { Bottom of } \\
\text { footing/pile } \\
\text { elevation } \\
\text { (feet) }\end{array}$ & $\begin{array}{l}\text { Channel } \\
\text { elevation at } \\
\text { abutment/ } \\
\text { pier }^{2} \\
\text { (feet) }\end{array}$ & $\begin{array}{l}\text { Contraction } \\
\text { scour depth } \\
\text { (feet) }\end{array}$ & $\begin{array}{l}\text { Abutment } \\
\text { scour } \\
\text { depth } \\
\text { (feet) }\end{array}$ & $\begin{array}{l}\text { Pier } \\
\text { scour } \\
\text { depth } \\
\text { (feet) }\end{array}$ & $\begin{array}{l}\text { Depth of } \\
\text { total scour } \\
\text { (feet) }\end{array}$ & $\begin{array}{c}\text { Elevation of } \\
\text { scour }^{2} \\
\text { (feet) }\end{array}$ & $\begin{array}{c}\text { Remaining } \\
\text { footing/pile } \\
\text { depth } \\
\text { (feet) }\end{array}$ \\
\hline \multicolumn{12}{|c|}{100 -yr. discharge is 2,400 cubic-feet per second } \\
\hline Left abutment & 0.0 & -- & 497.9 & -- & 489.6 & 1.8 & 15.4 & -- & 17.2 & 472.4 & -- \\
\hline Right abutment & 22.2 & -- & 497.8 & -- & 490.8 & 1.8 & 8.6 & -- & 10.4 & 480.4 & -- \\
\hline
\end{tabular}

1.Measured along the face of the most constricting side of the bridge.

2.Arbitrary datum for this study.

Table 2. Remaining footing/pile depth at abutments for the 500-year discharge at structure SHEFTH00410018 on Town Highway 41, crossing Millers Run, Sheffield, Vermont. [VTAOT, Vermont Agency of Transportation; --, no data]

\begin{tabular}{|c|c|c|c|c|c|c|c|c|c|c|c|}
\hline Description & Station $^{1}$ & $\begin{array}{l}\text { VTAOT } \\
\text { minimum } \\
\text { low-chord } \\
\text { elevation } \\
\text { (feet) }\end{array}$ & $\begin{array}{l}\text { Surveyed } \\
\text { minimum } \\
\text { low-chord } \\
\text { elevation } \\
\text { (feet) }\end{array}$ & $\begin{array}{c}\text { Bottom of } \\
\text { footing/pile } \\
\text { elevation } \\
\text { (feet) }\end{array}$ & $\begin{array}{c}\text { Channel } \\
\text { elevation at } \\
\text { abutment/ } \\
\text { pier }^{2} \\
\text { (feet) }\end{array}$ & $\begin{array}{c}\text { Contraction } \\
\text { scour depth } \\
\text { (feet) }\end{array}$ & $\begin{array}{l}\text { Abutment } \\
\text { scour } \\
\text { depth } \\
\text { (feet) }\end{array}$ & $\begin{array}{l}\text { Pier } \\
\text { scour } \\
\text { depth } \\
\text { (feet) }\end{array}$ & $\begin{array}{l}\text { Depth of } \\
\text { total scour } \\
\text { (feet) }\end{array}$ & $\begin{array}{c}\text { Elevation of } \\
\text { scour }^{2} \\
\text { (feet) }\end{array}$ & $\begin{array}{c}\text { Remaining } \\
\text { footing/pile } \\
\text { depth } \\
\text { (feet) }\end{array}$ \\
\hline \multicolumn{12}{|c|}{500 -yr. discharge is 2,950 cubic-feet per second } \\
\hline Left abutment & 0.0 & -- & 497.9 & -- & 489.6 & 1.8 & 16.4 & -- & 18.2 & 471.4 & -- \\
\hline Right abutment & 22.2 & -- & 497.8 & -- & 490.8 & 1.8 & 6.9 & -- & 8.7 & 482.1 & -- \\
\hline
\end{tabular}

1.Measured along the face of the most constricting side of the bridge.

2.Arbitrary datum for this study. 


\section{SELECTED REFERENCES}

Arcement, G.J., Jr., and Schneider, V.R., 1989, Guide for selecting Manning's roughness coefficients for natural channels and flood plains: U.S. Geological Survey Water-Supply Paper 2339, 38 p.

Barnes, H.H., Jr., 1967, Roughness characteristics of natural channels: U.S. Geological Survey Water-Supply Paper 1849,213 p.

Benson, M. A., 1962, Factors Influencing the Occurrence of Floods in a Humid Region of Diverse Terrain: U.S. Geological Survey WaterSupply Paper 1580-B, 64 p.

Brown, S.A. and Clyde, E.S., 1989, Design of riprap revetment: Federal Highway Administration Hydraulic Engineering Circular No. 11, Publication FHWA-IP-89-016, 156 p.

Federal Highway Administration, 1983, Runoff estimates for small watersheds and development of sound design: Federal Highway Administration Report FHWA-RD-77-158.

Federal Highway Administration, 1993, Stream Stability and Scour at Highway Bridges: Participant Workbook: Federal Highway Administration Report FHWA-HI-91-011.

Froehlich, D.C., 1989, Local scour at bridge abutments in Ports, M.A., ed., Hydraulic Engineering--Proceedings of the 1989 National Conference on Hydraulic Engineering: New York, American Society of Civil Engineers, p. 13-18.

Hayes, D.C.,1993, Site selection and collection of bridge-scour data in Delaware, Maryland, and Virginia: U.S. Geological Survey WaterResources Investigation Report 93-4017, 23 p.

Interagency Advisory Committee on Water Data, 1982, Guidelines for determining flood flow frequency: U.S. Geological Survey, Bulletin 17B of the Hydrology Subcommittee, 190 p.

Johnson, C.G. and Tasker, G.D.,1974, Progress report on flood magnitude and frequency of Vermont streams: U.S. Geological Survey OpenFile Report 74-130, 37 p.

Lagasse, P.F., Schall, J.D., Johnson, F., Richardson, E.V., Chang, F., 1995, Stream Stability at Highway Structures: Federal Highway Administration Hydraulic Engineering Circular No. 20, Publication FHWA-IP-90-014, 144 p.

Laursen, E.M., 1960, Scour at bridge crossings: Journal of the Hydraulics Division, American Society of Civil Engineers, v. 86, no. HY2, p. 39-53.

Potter, W. D., 1957a, Peak rates of runoff in the Adirondack, White Mountains, and Maine woods area, Bureau of Public Roads

Potter, W. D., 1957b, Peak rates of runoff in the New England Hill and Lowland area, Bureau of Public Roads

Richardson, E.V. and Davis, S.R., 1995, Evaluating scour at bridges: Federal Highway Administration Hydraulic Engineering Circular No. 18, Publication FHWA-IP-90-017, 204 p.

Richardson, E.V., Simons, D.B., and Julien, P.Y., 1990, Highways in the river environment: Federal Highway Administration Publication FHWA-HI-90-016.

Ritter, D.F., 1984, Process Geomorphology: W.C. Brown Co., Debuque, Iowa, 603 p.

Shearman, J.O., 1990, User's manual for WSPRO--a computer model for water surface profile computations: Federal Highway Administration Publication FHWA-IP-89-027, 187 p.

Shearman, J.O., Kirby, W.H., Schneider, V.R., and Flippo, H.N., 1986, Bridge waterways analysis model; research report: Federal Highway Administration Publication FHWA-RD-86-108, 112 p.

Talbot, A.N., 1887, The determination of water-way for bridges and culverts.

U.S. Department of Transportation, 1993, Stream stability and scour at highway bridges, Participant Workbook: Federal Highway Administration Publication FHWA HI-91-011.

U.S. Geological Survey, 1988, Lyndonville, Vermont 7.5 Minute Series quadrangle map: U.S. Geological Survey Topographic Maps, Scale $1: 24,000$.

U.S. Geological Survey, 1986, Stannard, Vermont 7.5 Minute Series quadrangle map: U.S. Geological Survey Topographic Maps, Scale 1:24,000. 


\section{APPENDIX A: \\ WSPRO INPUT FILE}




\section{WSPRO INPUT FILE}

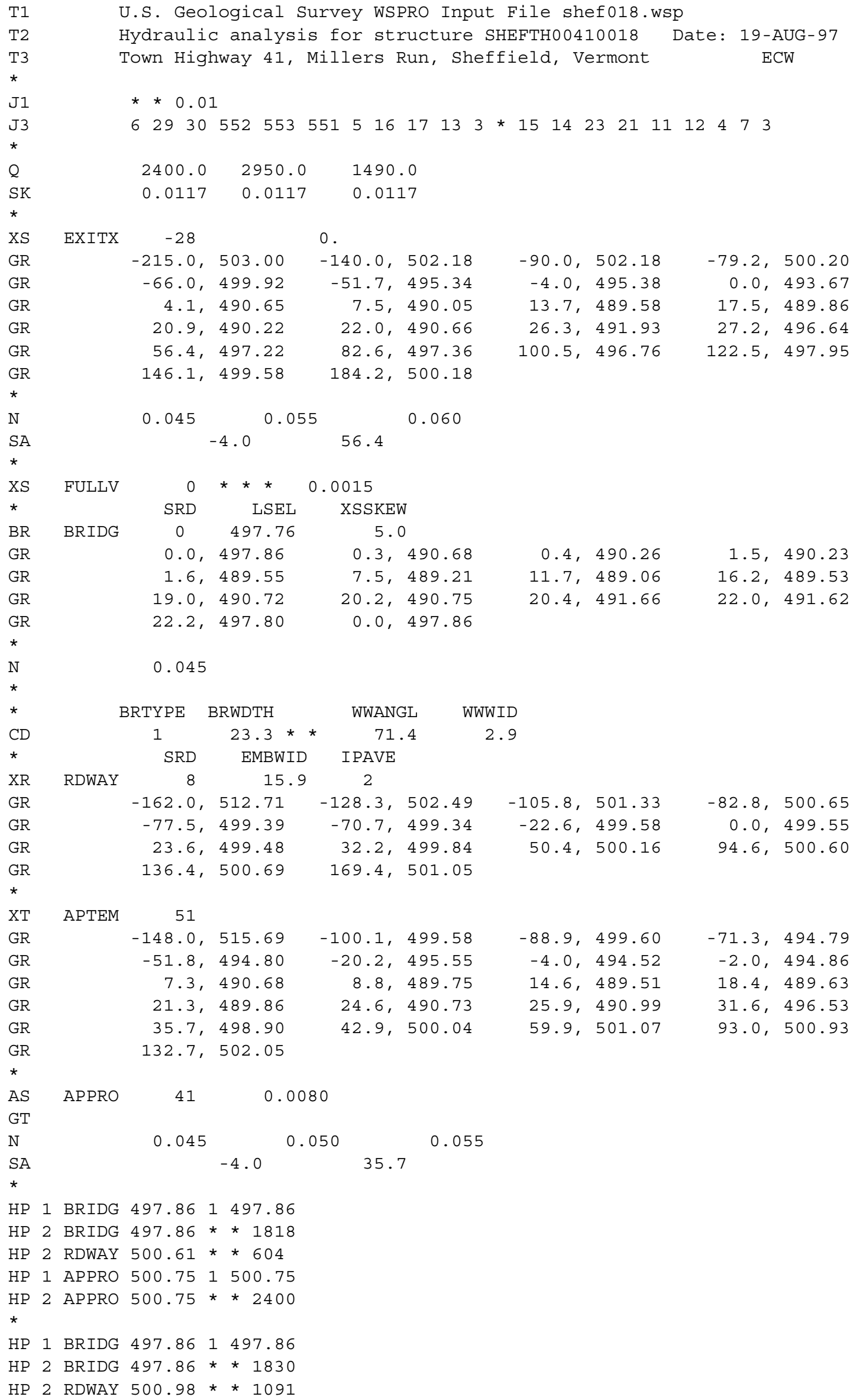




\section{APPENDIX B: \\ WSPRO OUTPUT FILE}


WSPRO OUTPUT FILE

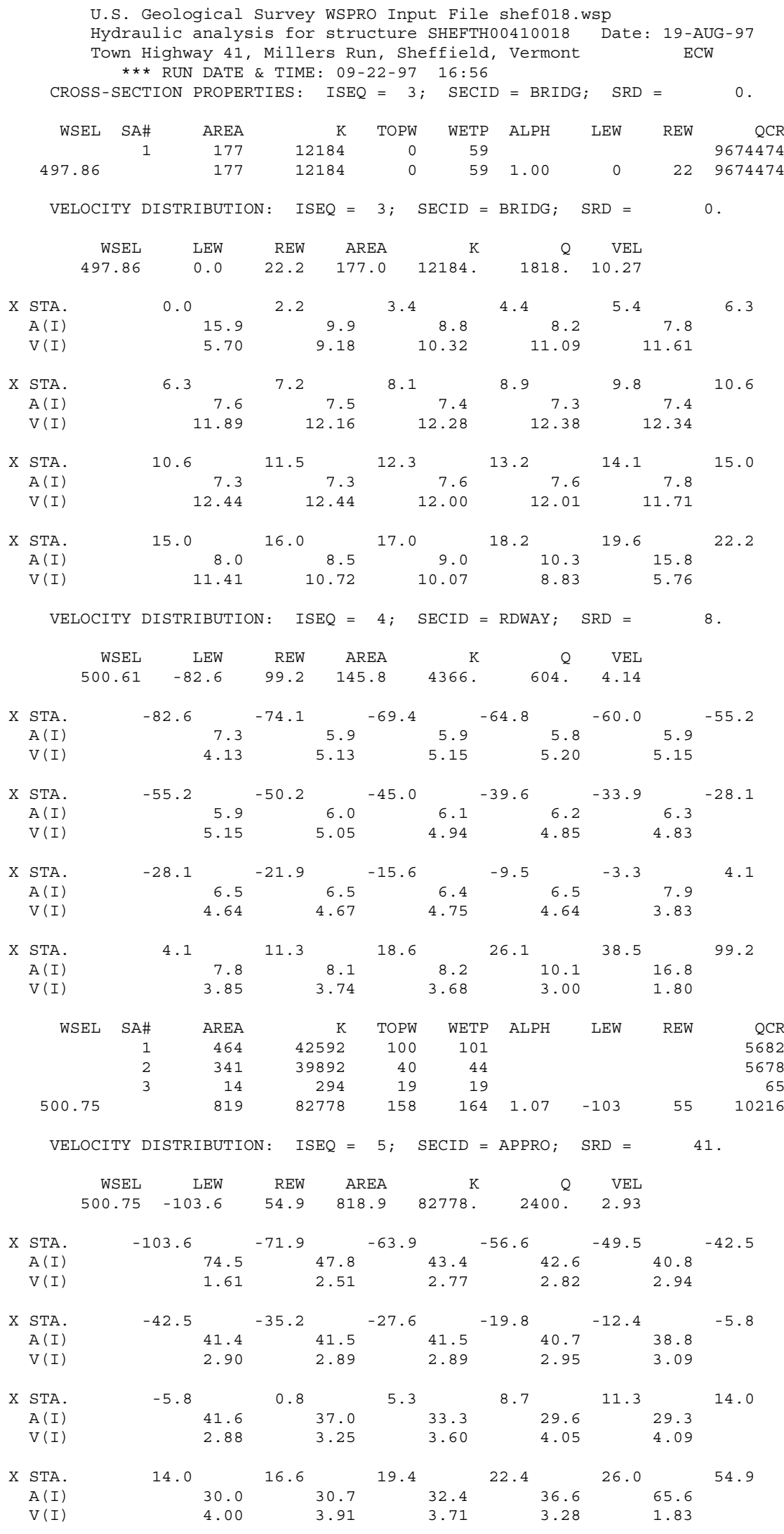


WSPRO OUTPUT FILE (continued)

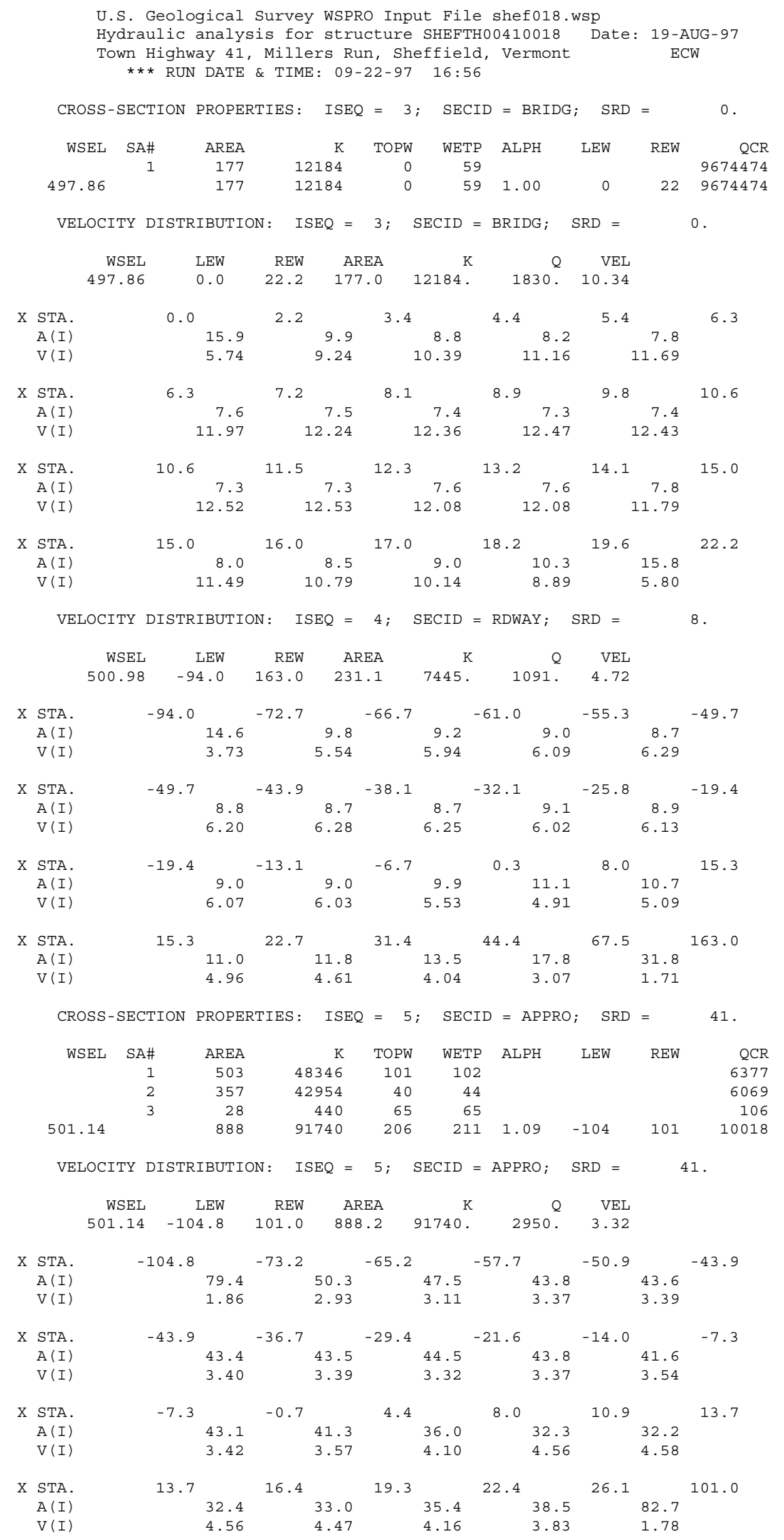


WSPRO OUTPUT FILE (continued)

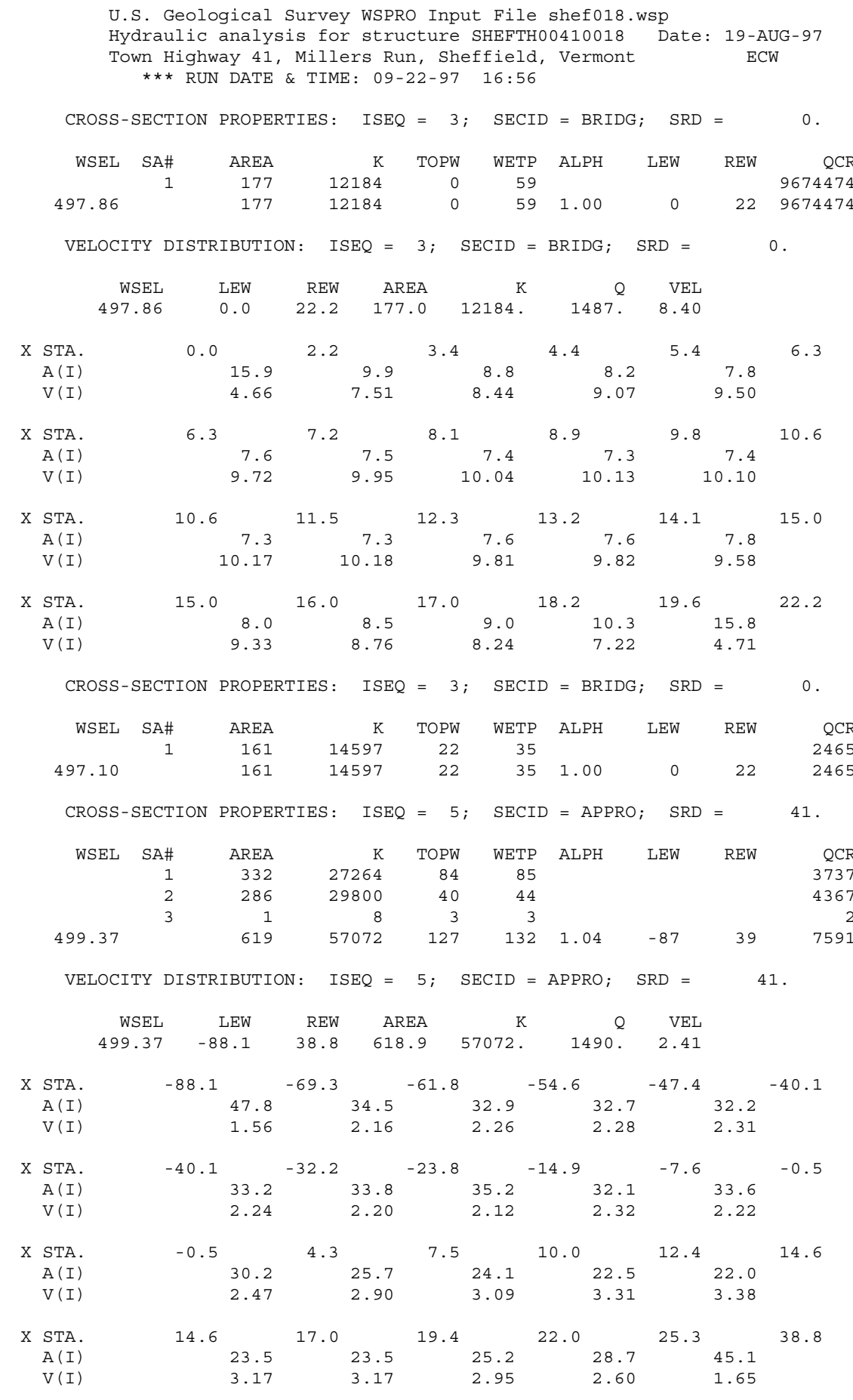


WSPRO OUTPUT FILE (continued)

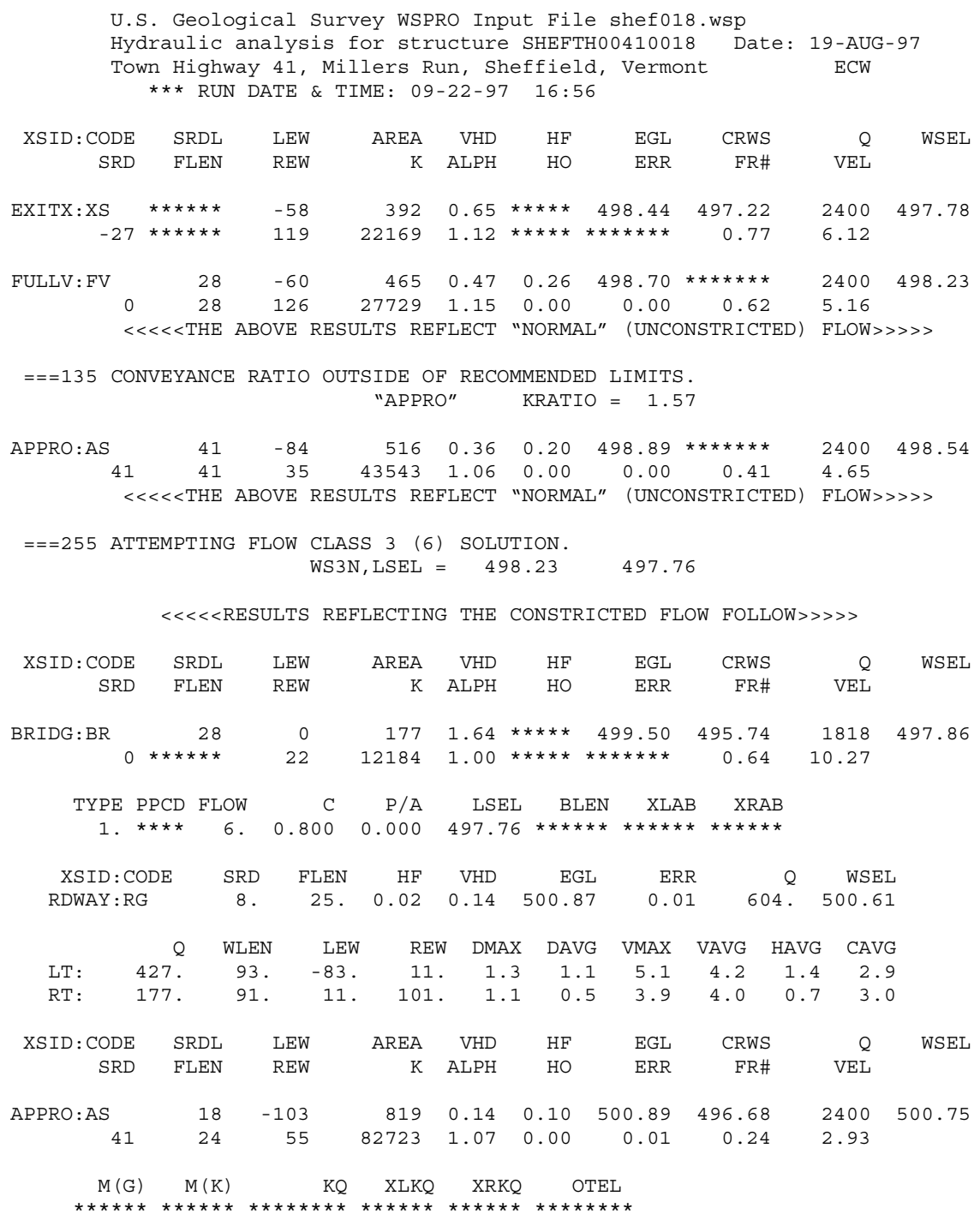

$<<<<$ END OF BRIDGE COMPUTATIONS $>>>>>$

FIRST USER DEFINED TABLE.

\begin{tabular}{|c|c|c|c|c|c|c|c|c|}
\hline XSID : CODE & SRD & LEW & REW & Q & $\mathrm{K}$ & AREA & VEL & WSEL \\
\hline EXITX:XS & -28 & -59. & 119. & 2400. & 22169 . & 392 . & 6.12 & 497.78 \\
\hline FULLV: FV & 0 & -61. & 126. & 2400 . & 27729 . & 465. & 5.16 & 498.23 \\
\hline BRIDG : BR & 0 . & 0 . & 22 . & 1818. & 12184. & 177 . & 10.27 & 497.86 \\
\hline RDWAY : RG & 8 & $* \star * \star * *$ & 427 . & 604 & $* \star * * * * * *$ & $\star \star \star \star * *$ & 2.00 & 500.61 \\
\hline APPRO:AS & 41 & -104 & 55. & 2400 . & 82723. & 819. & 2.93 & 500.75 \\
\hline XSID : CODE & XLKQ & XRKQ & & & & & & \\
\hline
\end{tabular}

SECOND USER DEFINED TABLE.

$\begin{array}{lcrrrrrrrr}\text { XSID :CODE } & \text { CRWS } & \text { FR\# } & \text { YMIN } & \text { YMAX } & \text { HF } & \text { HO } & \text { VHD } & \text { EGL } & \text { WSEL } \\ \text { EXITX:XS } & 497.22 & 0.77 & 489.58 & 503.00 * * * * * * * * * * * & 0.65 & 498.44 & 497.78 \\ \text { FULLV :FV } & * * * * * * * & 0.62 & 489.62 & 503.04 & 0.26 & 0.00 & 0.47 & 498.70 & 498.23 \\ \text { BRIDG :BR } & 495.74 & 0.64 & 489.06 & 497.86 * * * * * * * * * * * & 1.64 & 499.50 & 497.86 \\ \text { RDWAY :RG } & * * * * * * * * * * * * * * & 499.34 & 512.71 & 0.02 * * * * * * & 0.14 & 500.87 & 500.61 \\ \text { APPRO :AS } & 496.68 & 0.24 & 489.49 & 515.67 & 0.10 & 0.00 & 0.14 & 500.89 & 500.75\end{array}$


WSPRO OUTPUT FILE (continued)

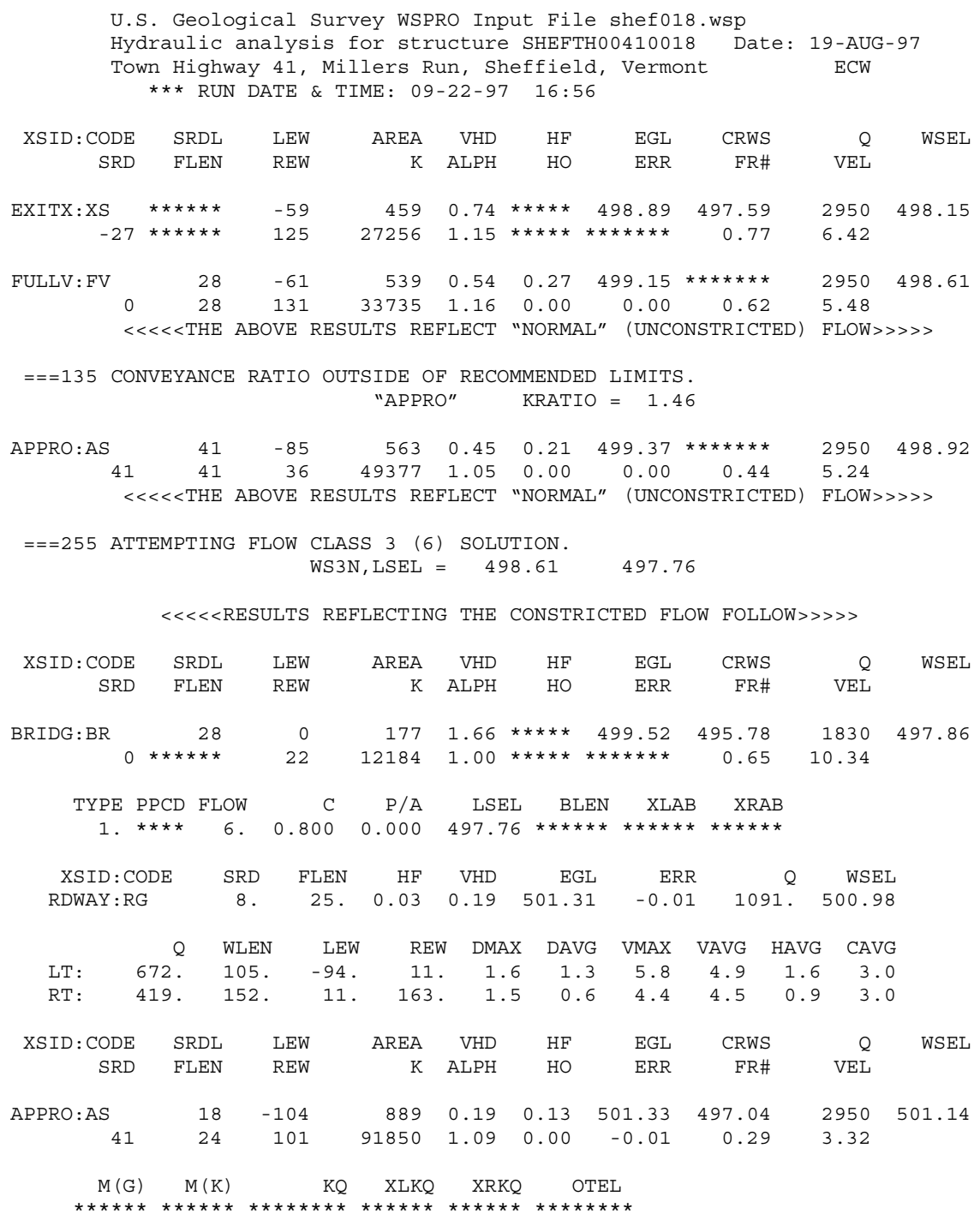

$<<<<$ END OF BRIDGE COMPUTATIONS $>>>>>$

FIRST USER DEFINED TABLE.

\begin{tabular}{|c|c|c|c|c|c|c|c|c|}
\hline XSID: CODE & SRD & LEW & REW & Q & $\mathrm{K}$ & AREA & VEL & WSEL \\
\hline EXITX:XS & -28 & -60 & 125. & 2950 . & 27256 . & 459. & 6.42 & 498.15 \\
\hline FULLV : FV & 0 & -62 . & 131. & 2950 . & 33735 . & 539. & 5.48 & 498.61 \\
\hline BRIDG : BR & 0 . & 0 & 22 & 1830. & 12184. & 177. & 10.34 & 497.86 \\
\hline RDWAY : RG & $8 . *$ & $\star \star \star \star \star \star *$ & 672 . & 1091. & 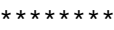 & $* * * * *$ & 2.00 & 500.98 \\
\hline APPRO:AS & 41 & -105. & 101. & 2950 . & 91850 & 889. & 3.32 & 501.14 \\
\hline XSID : CODE & XLKQ & XRKQ & & & & & & \\
\hline
\end{tabular}

SECOND USER DEFINED TABLE.

$\begin{array}{lcrrrrrrrr}\text { XSID:CODE } & \text { CRWS } & \text { FR\# } & \text { YMIN } & \text { YMAX } & \text { HF } & \text { HO } & \text { VHD } & \text { EGL } & \text { WSEL } \\ \text { EXITX:XS } & 497.59 & 0.77 & 489.58 & 503.00 * * * * * * * * * * * & 0.74 & 498.89 & 498.15 \\ \text { FULLV:FV } & * * * * * * * & 0.62 & 489.62 & 503.04 & 0.27 & 0.00 & 0.54 & 499.15 & 498.61 \\ \text { BRIDG:BR } & 495.78 & 0.65 & 489.06 & 497.86 * * * * * * * * * * * & 1.66 & 499.52 & 497.86 \\ \text { RDWAY:RG } & * * * * * * * * * * * * * * & 499.34 & 512.71 & 0.03 * * * * * & 0.19 & 501.31 & 500.98 \\ \text { APPRO:AS } & 497.04 & 0.29 & 489.49 & 515.67 & 0.13 & 0.00 & 0.19 & 501.33 & 501.14\end{array}$


WSPRO OUTPUT FILE (continued)

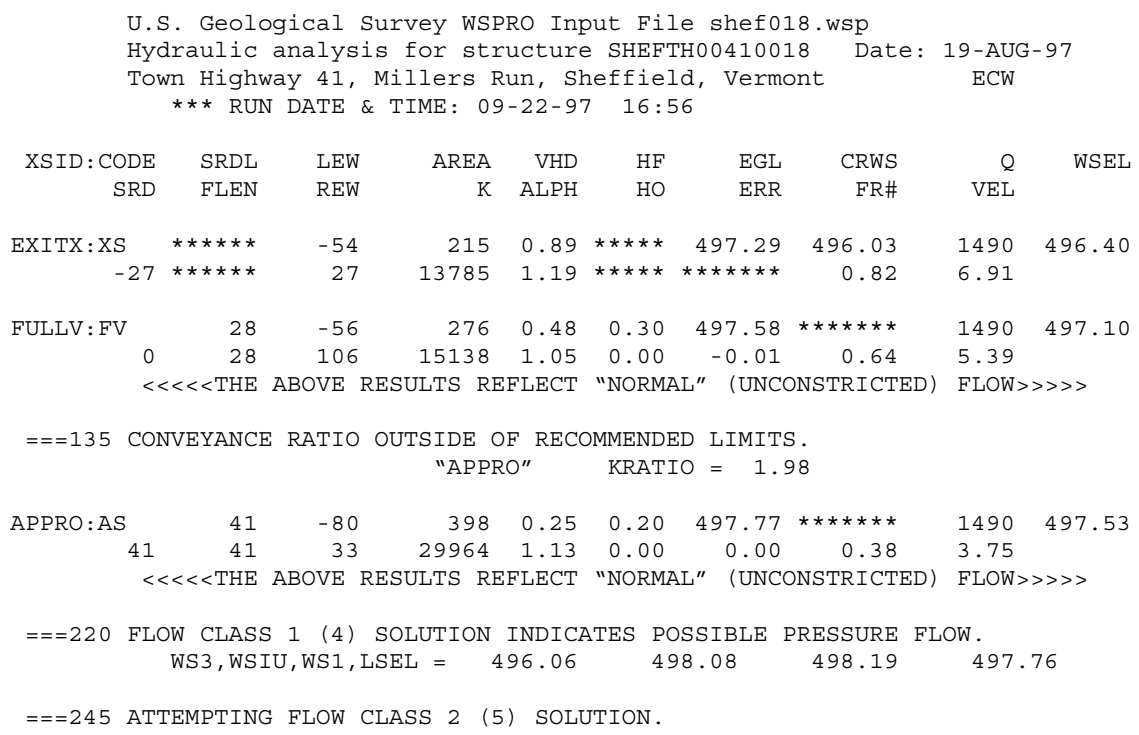

FIRST USER DEFINED TABLE.

\begin{tabular}{|c|c|c|c|c|c|c|c|c|}
\hline XSID : CODE & SRD & LEW & REW & 0 & $\mathrm{~K}$ & AREA & VEL & WSEL \\
\hline EXITX:XS & -28. & -55 & 27. & 1490. & 13785. & 215. & 6.91 & 496.40 \\
\hline FULLV : FV & 0 . & -57. & 106. & 1490. & 15138. & 276 . & 5.39 & 497.10 \\
\hline BRIDG : BR & 0 . & 0 & 22 . & 1487. & 12184. & 177. & 8.40 & 497.86 \\
\hline RDWAY : RG & 8. & $\star \star \star \star \star \star *$ & $\star \star \star * *$ & 0 . & 0 . & 0 . & 2.00 & 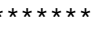 \\
\hline APPRO : AS & 41. & -88 & 39. & 1490. & 57065. & 619. & 2.41 & 499.37 \\
\hline XSID : CODE & XLKQ & XRKQ & & & & & & \\
\hline
\end{tabular}

SECOND USER DEFINED TABLE.

\begin{tabular}{|c|c|c|c|c|c|c|c|c|c|}
\hline XSID : CODE & CRWS & FR\# & YMIN & YMAX & $\mathrm{HF}$ & $\mathrm{HO}$ & VHD & EGL & WSEL \\
\hline EXITX:XS & 496.03 & 0.82 & 489.58 & $503.00 *$ & 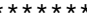 & 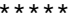 & 0.89 & 497.29 & 496.40 \\
\hline FULLV : FV & 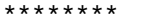 & 0.64 & 489.62 & 503.04 & 0.30 & 0.00 & 0.48 & 497.58 & 497.10 \\
\hline BRIDG : BR & 494.99 & 0.52 & 489.06 & 497.86 * & $* * * * * * *$ & $\star \star \star \star \star *$ & 1.10 & 498.96 & 497.86 \\
\hline RDWAY : RG & $\star \star \star \star \star \star * \star * \star * \star * *$ & $* * \star * *$ & 499.34 & $512.71 *$ & $* * * * * * *$ & $\star \star \star \star * *$ & 0.09 & 499.45 * & 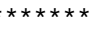 \\
\hline APPRO: AS & 495.85 & 0.20 & 489.49 & 515.67 & 0.07 & 0.37 & 0.09 & 499.46 & 499.37 \\
\hline
\end{tabular}

NORMAL END OF WSPRO EXECUTION. 


\section{APPENDIX C:}

\section{BED-MATERIAL PARTICLE-SIZE DISTRIBUTION}




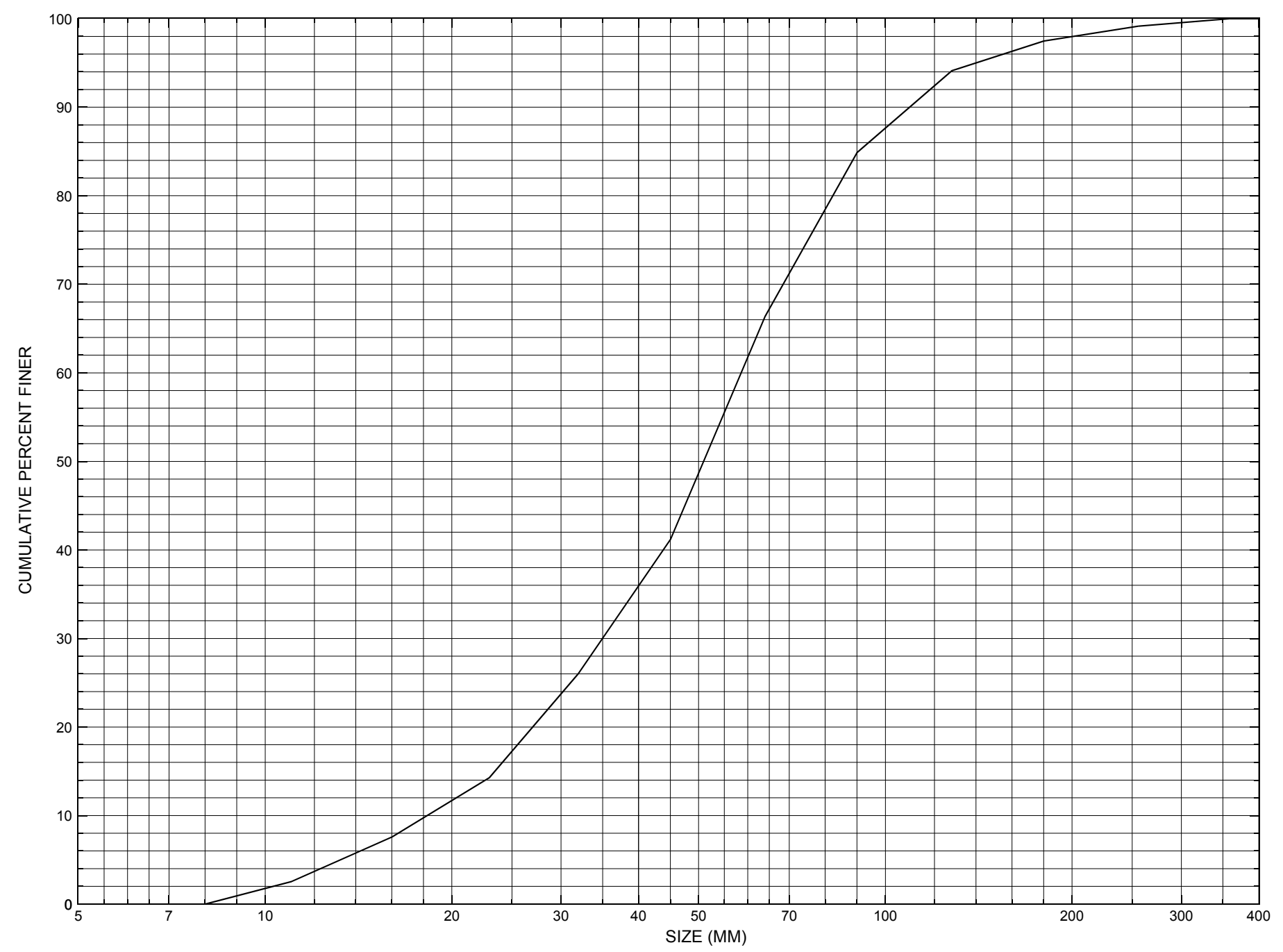

Appendix C. Bed material particle-size distribution for a pebble count in the channel approach of structure SHEFTH00410018, in Sheffield, Vermont. 


\section{APPENDIX D: \\ HISTORICAL DATA FORM}




\section{Structure Number SHEFTH00410018}

\section{General Location Descriptive}

Data collected by (First Initial, Full last name) $\mathbf{E}$. BOEHMLER

Date $(M M / D D / Y Y) \_\mathbf{0 3} / \underline{\mathbf{2 8}} / \underline{\mathbf{9 5}}$

Highway District Number (I - 2; nn) $\mathbf{0 7}$

Town (FIPS place code; I - 4; nnnnn) $\mathbf{6 4 0 7 5}$

Waterway (I - 6) MILLERS RUN

Route Number $\underline{\text { TH041 }}$

Topographic Map Lyndonville

Latitude (I - 16; nnnn.n) $\mathbf{4 4 3 6 3}$
County (FIPS county code; I - 3; nnn)

Mile marker (I - 11; nnn.nnn) $\mathbf{0 0 0 0 0 0}$

Road Name (I - 7): -

Vicinity (I - 9) 0.1 MI JCT TH 41 + VT122

Hydrologic Unit Code: $\mathbf{0 1 0 8 0 1 0 2}$

Longitude (i - 17; nnnnn.n) $\mathbf{7 2 0 7 0}$

\section{Select Federal Inventory Codes}

FHWA Structure Number $(I$ - 8) $\mathbf{1 0 0 3 1 2 0 0 1 8 0 3 1 2}$

Maintenance responsibility $(I-21 ; n n) \quad \mathbf{0 3}$

Year built (I - 27; YYYY) 1973

Average daily traffic, ADT (I - 29; nnnnnn) $\underline{000020}$

Year of ADT (I - 30; YY) $\mathbf{9 2}$

Opening skew to Roadway $(I-34 ; n n) \quad \mathbf{0 0}$

Operational status $(I-41 ; X) \quad \mathbf{A}$

Structure type (I - 43; nnn) $\mathbf{3 0 2}$

Approach span structure type $(I-44 ; n n n) \quad \mathbf{0 0 0}$

Number of spans (I - 45; nnn) $\mathbf{0 0 1}$

Number of approach spans (I - 46; nnnn) $\mathbf{0 0 0 0}$

Comments:

The structural inspection report of 10/31/94 indicates the structure is a steel stringer type bridge with a timber deck. The abutment walls and wingwalls are concrete. Both wingwalls on the left abutment are reported as having alligator cracks and leaks with areas of spalling and section loss along their tops and ends. The right abutment is actually concrete faced "laid-up" stone blocks. The concrete facing is reported as fairly new. Stone and boulder fill is reported along the banks upstream and downstream of the bridge. There also are reported signs of bank erosion from previous flooding. Point bars and debris accumulation problems are noted as minor at this site.
Maximum span length (I - 48; nnnn) $\underline{\mathbf{0 0 2 8}}$

Structure length (I - 49; nnnnnn) $\underline{000030}$

Deck Width (I - 52; nn.n) 159

Channel \& Protection $(I-61 ; n) \underline{5}$

Waterway adequacy $(I-71 ; n) \underline{6}$

Underwater Inspection Frequency $(I-92 B ; X Y Y) \_$N

Year Reconstructed (I - 106) $\mathbf{0 0 0 0}$

Clear span (nnn.n ft) $\quad \mathbf{0 2 2 . 4}$

Vertical clearance from streambed (nnn.n ft) $\underline{\mathbf{0 0 7 . 5}}$

Waterway of full opening $\left(n n n . n t^{2}\right) \quad \mathbf{1 6 8 . 0}$ 


\section{Bridge Hydrologic Data}

Is there hydrologic data available? $\underline{\mathbf{N}}$ if No, type ctrl-n $h \quad$ VTAOT Drainage area $\left(m i^{2}\right)$ : -

Terrain character:

Stream character \& type: -

Streambed material:

Discharge Data (cfs):

$$
\begin{aligned}
& Q_{2.33}- \\
& Q_{50}-
\end{aligned}
$$

Record flood date $(M M / D D / Y Y)$ :

Estimated Discharge (cfs): Ice conditions (Heavy, Moderate, Light) : -

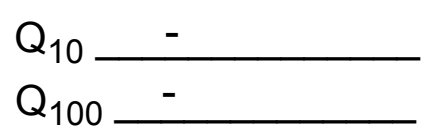

$$
\begin{aligned}
& Q_{25}- \\
& Q_{500}-
\end{aligned}
$$

Water surface elevation $(f t):-$

The stage increases to maximum highwater elevation (Rapidly, Not rapidly):

The stream response is (Flashy, Not flashy):

Describe any significant site conditions upstream or downstream that may influence the stream's stage: -

Watershed storage area (in percent): _ _ \%

The watershed storage area is: - (1-mainly at the headwaters; 2- uniformly distributed; 3-immediatly upstream oi the site)

Water Surface Elevation Estimates for Existing Structure:

\begin{tabular}{|l|l|l|l|l|l|}
\hline Peak discharge frequency & $Q_{2.33}$ & $Q_{10}$ & $Q_{25}$ & $Q_{50}$ & $Q_{100}$ \\
Water surface elevation (ft)) & - & - & - & - & - \\
Velocity (ft/sec) & - & - & - & - & - \\
\hline
\end{tabular}

Long term stream bed changes: -

Is the roadway overtopped below the $\mathrm{Q}_{100}$ ? (Yes, No, Unknown): $\mathbf{U}$ Frequency: Relief Elevation (ft): Discharge over roadway at $Q_{100}\left(f^{3} / \mathrm{sec}\right)$ :

Are there other structures nearby? (Yes, No, Unknown): $\underline{\mathbf{U}}$ Upstream distance (miles): Town: If No or Unknown, type ctrl-n os Highway No. : Structure No. : Year Built:

Clear span (ft): Clear Height $(f t)$ : Full Waterway $\left(f^{2}\right)$ : 
Downstream distance (miles): Town: Year Built:

Highway No. : Structure No. : Structure Type:

Clear span (ft): Clear Height $(f t)$ : Full Waterway $\left(f^{2}\right)$ : -

Comments:

\section{USGS Watershed Data}

Watershed Hydrographic Data Drainage area $(D A) \underline{16.24} \mathrm{mi}^{2}$

Watershed storage (ST) $\quad 0.9$

Bridge site elevation 925

Main channel length 6.36 Lake/pond/swamp area 0.15 $\mathrm{mi}^{2}$ $\%$ $10 \%$ channel length elevation $\mathbf{9 4 5}$ $\mathrm{ft} \quad 85 \%$ channel length elevation $\mathrm{ft}$

Main channel slope $(S)$

(S) 129.92 $\mathrm{ft} / \mathrm{mi}$

Watershed Precipitation Data

Average site precipitation in Average headwater precipitation in

Maximum 2yr-24hr precipitation event $(124,2)$ in

Average seasonal snowfall (Sn) $\mathrm{ft}$ 


\section{Bridge Plan Data}

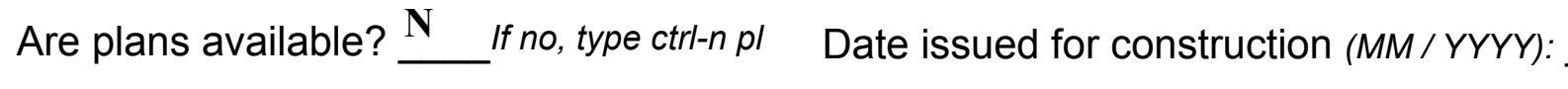

Project Number

Minimum channel bed elevation:

Low superstructure elevation: USLAB DSLAB USRAB DSRAB Benchmark location description:

NO BENCHMARK INFORMATION

Reference Point (MSL, Arbitrary, Other): Datum (NAD27, NAD83, Other):

Foundation Type: 4

If 1 : Footing Thickness

If 2: Pile Type:

If 3: Footing bottom elevation:

Is boring information available? $\mathbf{N}$

Foundation Material Type: $\mathbf{3}$

(1-Spreadfooting; 2-Pile; 3- Gravity; 4-Unknown)

Footing bottom elevation: -

Briefly describe material at foundation bottom elevation or around piles:

NO FOUNDATION MATERIAL INFORMATION

Comments: 


\section{Cross-sectional Data}

Is cross-sectional data available? $\underline{\mathbf{Y}}$ If no, type ctrl-n xs

Source (FEMA, VTAOT, Other)? VTAOT

Cross section is of the downstream face. The low cord elevation is from the survey log done Comments: for this report dated 8/1/95. The low cord to bed length data is from the sketch attached to a bridge inspection report dated 10/31/94, the sketch is dated 9/9/92.

\begin{tabular}{|l|l|l|l|l|l|l|l|l|l|l|l|}
\hline Station & $\mathbf{0}$ & $\mathbf{2 . 2 5}$ & 6.65 & $\mathbf{1 1 . 9}$ & $\mathbf{1 6 . 7}$ & $\mathbf{2 2 . 4}$ & - & - & - & - & - \\
\hline Feature & RAB & - & - & - & - & LAB & - & - & - & - & - \\
\hline $\begin{array}{l}\text { Low chord } \\
\text { elevation }\end{array}$ & 497.80 & 497.81 & 497.82 & 497.84 & 497.85 & 497.86 & - & - & - & - & - \\
\hline $\begin{array}{l}\text { Bed } \\
\text { elevation }\end{array}$ & 491.30 & 491.14 & 489.90 & 489.67 & 489.85 & 490.78 & - & - & - & - & - \\
\hline $\begin{array}{l}\text { Low chord- } \\
\text { bed }\end{array}$ & 6.5 & 6.67 & 7.92 & 8.17 & 8 & 7.08 & - & - & - & - & - \\
\hline Station & - & - & - & - & - & - & - & - & - & - & - \\
\hline Feature & - & - & - & - & - & - & - & - & - & - & - \\
\hline $\begin{array}{l}\text { Low chord } \\
\text { elevation }\end{array}$ & - & - & - & - & - & - & - & - & - & - & - \\
\hline $\begin{array}{l}\text { Bed } \\
\text { elevation }\end{array}$ & - & - & - & - & - & - & - & - & - & - & - \\
\hline $\begin{array}{l}\text { Low chord- } \\
\text { bed }\end{array}$ & - & - & - & - & - & - & - & - & - & - & - \\
\hline
\end{tabular}

Source (FEMA, VTAOT, Other)?

Comments: -

\begin{tabular}{|l|l|l|l|l|l|l|l|l|l|l|l|}
\hline Station & - & - & - & - & - & - & - & - & - & - & - \\
\hline Feature & - & - & - & - & - & - & - & - & - & - & - \\
\hline $\begin{array}{l}\text { Low chord } \\
\text { elevation }\end{array}$ & - & - & - & - & - & - & - & - & - & - & - \\
\hline $\begin{array}{l}\text { Bed } \\
\text { elevation }\end{array}$ & - & - & - & - & - & - & - & - & - & - & - \\
\hline $\begin{array}{l}\text { Low chord- } \\
\text { bed }\end{array}$ & - & - & - & - & - & - & - & - & - & - & - \\
\hline Station & - & - & - & - & - & - & - & - & - & - & - \\
\hline Feature & - & - & - & - & - & - & - & - & - & - & - \\
\hline $\begin{array}{l}\text { Low chord } \\
\text { elevation }\end{array}$ & - & - & - & - & - & - & - & - & - & - & - \\
\hline $\begin{array}{l}\text { Bed } \\
\text { elevation }\end{array}$ & - & - & - & - & - & - & - & - & - & - & - \\
\hline $\begin{array}{l}\text { Low chord- } \\
\text { bed }\end{array}$ & - & - & - & - & - & - & - & - & - & - & - \\
\hline
\end{tabular}




\section{APPENDIX E: \\ LEVEL I DATA FORM}


U. S. Geological Survey

Bridge Field Data Collection and Processing Form

Qa/Qc Check by: EW Date: $\underline{\mathbf{0 3} / 20 / 96}$

\section{Structure Number SHEFTH00410018}

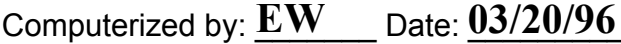

Reviewd by: $\quad$ EW Date: $\underline{\text { 9/29/97 }}$

\section{A. General Location Descriptive}

1. Data collected by (First Initial, Full last name) E. BOEHMLER

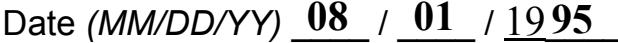

2. Highway District Number 07

County Calendonia (005)

Mile marker -

Waterway (I - 6) Millers Run

Town Sheffield (64075)

Route Number TH041

Road Name -

3. Descriptive comments:

Hydrologic Unit Code: $\mathbf{0 1 0 8 0 1 0 2}$

The bridge is located $0.1 \mathrm{mi}$ from the intersection with TH41 and VT122.

\section{B. Bridge Deck Observations}
4. Surface cover... LBUS 4
RBUS 4
LBDS 4
RBDS 4
Overall 4

(2b us, ds,lb,rb: 1- Urban; 2- Suburban; 3- Row crops; 4- Pasture; 5- Shrub- and brushland; 6- Forest; 7- Wetland)
5. Ambient water surface... US 1
UB 1
DS 1
(1- pool; 2- riffle)

6. Bridge structure type 1 (1- single span; 2- multiple span; 3- single arch; 4- multiple arch; 5-cylindrical culvert; 6- box culvert; or 7- other)
7. Bridge length $\mathbf{3 0}$
(feet)
Span length 28
(feet)
Bridge width 15.9 (feet)

\section{Road approach to bridge:}
8. LB 1
RB 2
( 0 even, 1- lower, 2- higher)
9. LB_2
RB $\underline{2}$
(1- Paved, 2- Not paved)

10. Embankment slope (run / rise in feet / foot)

US left

US right

\begin{tabular}{|c|c|c|c|}
\hline \multicolumn{2}{|c|}{ Protection } & \multirow{2}{*}{ 13.Erosion } & 14.Severity \\
\hline 11.Type & 12.Cond. & $\underline{\mathbf{2}}$ & $\underline{\mathbf{2}}$ \\
\hline $\mathbf{0}$ & - & $\underline{\mathbf{2}}$ & $\underline{\mathbf{2}}$ \\
\hline $\mathbf{0}$ & - & $\underline{\mathbf{0}}$ & $\mathbf{0}$ \\
\hline $\mathbf{0}$ & - & $\mathbf{0}$ \\
\hline $\mathbf{0}$ & - & $\mathbf{0}$ & $\mathbf{0}$ \\
\hline
\end{tabular}

Bank protection types: 0- none; 1- < 12 inches;

2- < 36 inches; 3- < 48 inches;

4- < 60 inches; 5- wall / artificial levee

Bank protection conditions: 1- good; 2- slumped;

3- eroded; 4- failed

Erosion: 0 - none; 1- channel erosion; 2 -

road wash; 3- both; 4- other

Erosion Severity: 0 - none; 1- slight; 2- moderate; 3- severe

\section{Channel approach to bridge (BF):}

15. Angle of approach: $\mathbf{2 5}$

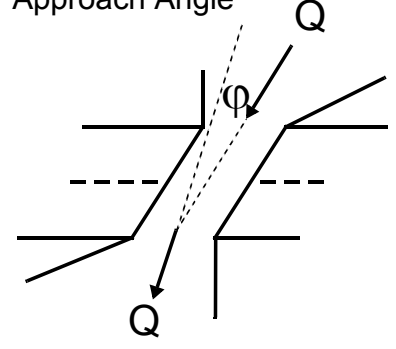

17. Channel impact zone 1:

Where? LB $(L B, R B)$

Range? 20 feet $\underline{\text { US }}$

Channel impact zone 2:

Where? RB (LB, RB)

Range? $\underline{30}$ feet $\underline{\mathbf{D S}}$

Impact Severity: 0- none to very slight; 1- Slight; 2- Moderate; 3- Severe
16. Bridge skew: $\mathbf{2 0}$ Bridge Skew Angle

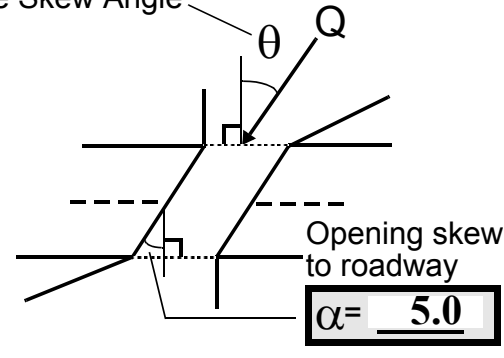

\section{Exist? $\mathbf{Y}(Y$ or $N)$}

Severity 1

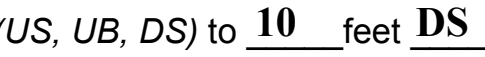

Exist? $\mathbf{Y}(Y$ or $N)$

Severity 1

$U B, D S)$ to $\underline{90 \quad \text { feet }} \underline{\mathbf{D S}}$ 
18. Bridge Type: 1a, 4

1a- Vertical abutments with wingwalls

1 b- Vertical abutments without wingwalls

2- Vertical abutments and wingwalls, sloping embankment

Wingwalls parallel to abut. face

3- Spill through abutments

4- Sloping embankment, vertical wingwalls and abutments

Wingwall angle less than $90^{\circ}$.

19. Bridge Deck Comments (surface cover variations, measured bridge and span lengths, bridge type variations,

approach overflow width, etc.)

\#7: Values are from VTAOT database. The measured bridge length equals 30 feet; bridge span equals 25.5

feet; bridge width equals 15.7 feet.

\#18: The LABUT is bridge type 4, while the RABUT is bridge type 1 a.

\section{Upstream Channel Assessment}

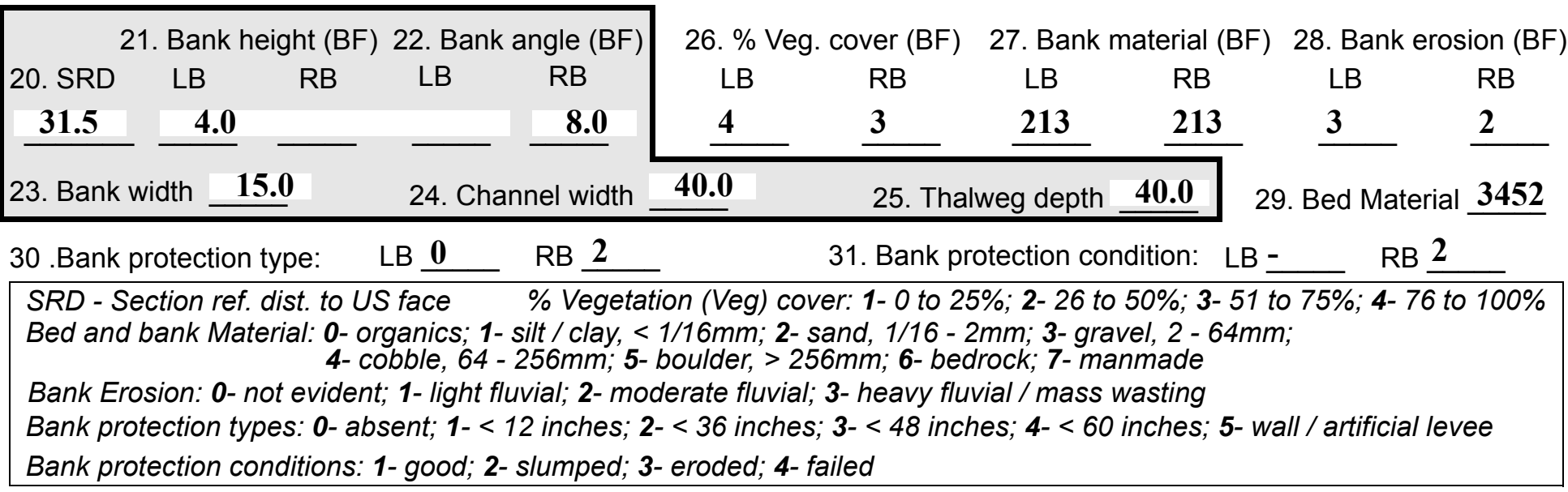

32. Comments (bank material variation, minor inflows, protection extent, etc.):

A log type drop structure exists at 106 feet US.

The LB is moderately scalloped, and does not have protection.

The RB protection has slipped about 2 feet from the top of the bank. A slip face is visible in the bank material above the stone fill, extending to the top of the bank. The protection extends from $0 \mathrm{ft}$ US to $40 \mathrm{ft}$ US. 
33.Point/Side bar present? $\mathbf{N}(Y$ or $N$. if $N$ type ctrl-n pb)34. Mid-bar distance: -

35. Mid-bar width: -

36. Point bar extent: feet (US, UB) to feet (US, UB, DS) positioned $\%$ LB to $\% \mathrm{RB}$

37. Material: -

38. Point or side bar comments (Circle Point or Side; Note additional bars, material variation, status, etc.):

NO POINT BARS

39. Is a cut-bank present? $\mathbf{Y}$ (Y or if $N$ type ctrl-n cb) 40. Where? $\underline{\mathbf{L B}}$ (LB or RB)

41. Mid-bank distance: $\mathbf{4 5}$ 42. Cut bank extent: 106 feet US (US, UB) to 7 feet $\underline{\mathbf{U S}}$ (US, UB, DS)

43. Bank damage: $\mathbf{3}$ (1- eroded and/or creep; 2- slip failure; 3- block failure)

44. Cut bank comments (eg. additional cut banks, protection condition, etc.):

Block failure is evident. From 55 feet US to 7 feet US, the bank is additionally eroded and moderately scalloped between trees and tree trunks. Also at this location, tree roots are exposed along the edge of the channel.

45. Is channel scour present? $\mathbf{N}$ (Yor if $N$ type ctrl-n cs)

47. Scour dimensions: Length Width Depth : 46. Mid-scour distance: -

48. Scour comments (eg. additional scour areas, local scouring process, etc.):

NO CHANNEL SCOUR

49. Are there major confluences? $\mathbf{N}$ ( $Y$ or if $N$ type ctrl-n $m c$ )

51. Confluence 1: Distance 52. Enters on Enters on - $\quad(L B$ or $R B)$ Confluence 2: Distance 54. Confluence comments (eg. confluence name):

NO MAJOR CONFLUENCES
50. How many? -

53. Type( 1- perennial; 2- ephemeral)

Type (1- perennial; 2- ephemeral)

\section{Under Bridge Channel Assessment}

55. Channel restraint (BF)? LB 2

\begin{tabular}{|c|c|}
\hline 56. Height (BF) & 57 Angle (BF) \\
\hline LB $\quad$ RB & LB $\quad R B$ \\
\hline 18.5 & 1.0 \\
\hline
\end{tabular}

58. Bank width (BF) = (1- natural bank; 2- abutment; 3- artificial levee)

Bed and bank Material: 0- organics; 1- silt / clay, < 1/16mm; 2- sand, 1/16 - 2mm; 3- gravel, 2 - 64mm; 4- cobble, 64 - 256mm; 5- boulder, > 256mm; 6- bedrock; 7- manmade

61. Material $(\mathrm{BF}) \quad$ 62. Erosion $(\mathrm{BF})$

LB RB LB RB

$2 \quad \mathbf{7} \quad \mathbf{7} \quad \underline{-}$

59. Channel width -
60. Thalweg depth $\lcm{90.0}$
63. Bed Material -

Bank Erosion: 0- not evident; 1- light fluvial; 2- moderate fluvial; 3- heavy fluvial / mass wasting

64. Comments (bank material variation, minor inflows, protection extent, etc.):

3452

The scour hole described in the downstream channel assessment extends under the bridge and along the left abutment. 
65. Debris and Ice Is there debris accumulation?

$(Y$ or $N)$ 66. Where? $\mathbf{N}$

(1- Upstream; 2- At bridge; 3-Both)

67. Debris Potential ( 1-Low; 2- Moderate; 3- High)

68. Capture Efficiency 2

(1-Low; 2- Moderate; 3- High)

69. Is there evidence of ice build-up? 1 (Y or $N)$

Ice Blockage Potential $\mathbf{N}$

(1-Low; 2-Moderate; 3- High)

70. Debris and Ice Comments:

1

With the significant amount of bank erosion and the dense vegetation on the banks, the potential of debris accumulation in the channel is moderate. The capture efficency and ice blockage potential are low because the channel is straight.

\begin{tabular}{|l|c|c|c|c|c|c|c|c|}
\hline Abutments & $\begin{array}{c}\text { 71. Attack } \\
\angle \mathrm{BF})\end{array}$ & $\begin{array}{c}\text { 72. Slope } \\
(\mathrm{Qmax})\end{array}$ & $\begin{array}{l}\text { 73. Toe } \\
\text { loc. (BF) }\end{array}$ & $\begin{array}{c}\text { 74. Scour } \\
\text { Condition }\end{array}$ & $\begin{array}{c}\text { 75. Scour } \\
\text { depth }\end{array}$ & $\begin{array}{c}\text { 76. Exposure } \\
\text { depth }\end{array}$ & 77. Material & 78. Length \\
\hline LABUT & & $\mathbf{1 0}$ & $\mathbf{9 0}$ & $\mathbf{2}$ & $\mathbf{2}$ & $\mathbf{1}$ & $\mathbf{1}$ & $\mathbf{9 0 . 0}$ \\
\hline RABUT & $\mathbf{1}$ & - & $\mathbf{9 0}$ & & & $\mathbf{2}$ & $\mathbf{2}$ & $\mathbf{2 4 . 5}$ \\
\hline
\end{tabular}

Pushed: $L B$ or RB

Toe Location (Loc.): 0- even, 1- set back, 2- protrudes

Scour cond.: 0- not evident; 1- evident (comment); 2- footing exposed; 3-undermined footing; 4- piling exposed; 5- settled; 6- failed

Materials: 1- Concrete; 2- Stone masonry or drywall; 3- steel or metal; 4- wood

79. Abutment comments (eg. undermined penetration, unusual scour processes, debris, etc.):

$\mathbf{0}$

1.5

1

The original right abutment was a stone wall, which still exists behind a more recent concrete wall abutment. The newer concrete wall is 1.5 feet thick with an exposed step footing (1.5 feet) for almost its entire length. Some stone fill is present along the base of the right abutment under a sand and silt layer.

80. Wingwalls:

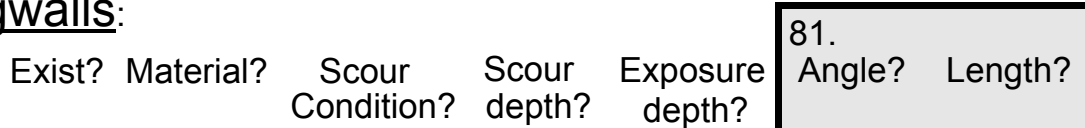

USLWW:

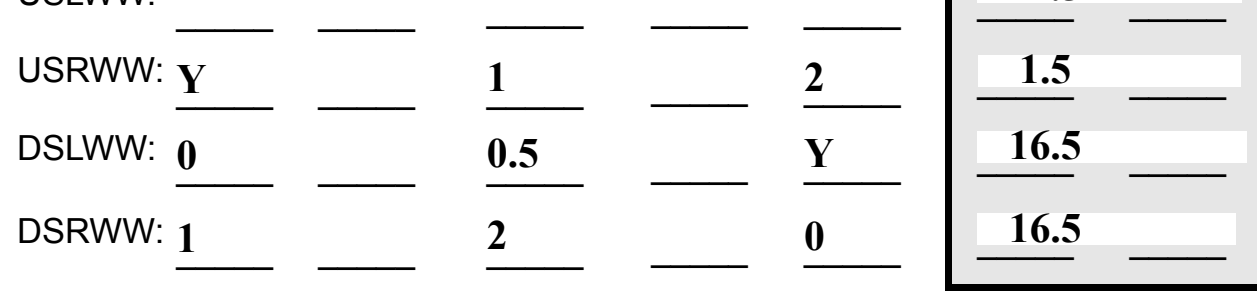

Wingwall materials: 1- Concrete; 2- Stone masonry or drywall; 3- steel or metal; 4- wood

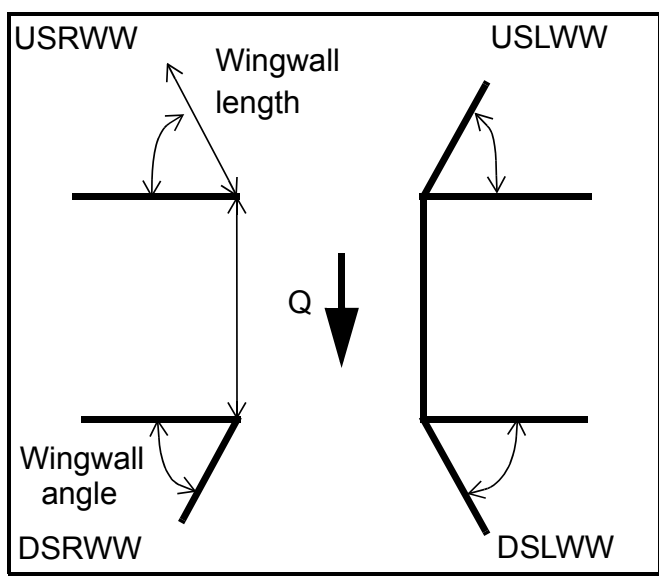

82. Bank / Bridge Protection:

\begin{tabular}{|l|l|l|l|l|l|l|l|l|}
\hline Location & USLWW & USRWW & LABUT & RABUT & LB & RB & DSLWW & DSRWW \\
\hline Type & $\mathbf{0 . 5}$ & $\mathbf{2}$ & $\mathbf{Y}$ & $\mathbf{0}$ & $\mathbf{1}$ & $\mathbf{1}$ & - & - \\
\hline Condition & $\mathbf{Y}$ & $\mathbf{0 . 5}$ & $\mathbf{1}$ & $\mathbf{0}$ & $\mathbf{1}$ & $\mathbf{1}$ & - & - \\
\hline Extent & $\mathbf{1}$ & $\mathbf{0 . 5}$ & $\mathbf{0}$ & $\mathbf{1}$ & $\mathbf{1}$ & $\mathbf{0}$ & $\mathbf{0}$ & - \\
\hline
\end{tabular}

Bank / Bridge protection types: 0- absent; 1- < 12 inches; 2- < 36 inches; 3- < 48 inches; 4- < 60 inches; 
83. Wingwall and protection comments (eg. undermined penetration, unusual scour processes, etc.):

-
-
-
-
-
2
1
3
0
-
-

\section{Piers:}

84. Are there piers? Th (Y or if $N$ type ctrl-n pr)

\begin{tabular}{|l|r|l|l|l|l|l|l|}
\hline \multirow{2}{*}{$\begin{array}{l}85 . \\
\text { Pier no. }\end{array}$} & \multicolumn{3}{|c|}{ width (w) feet } & \multicolumn{3}{c|}{ elevation (e) feet } \\
\cline { 2 - 8 } & w1 & w2 & w3 & e@w1 & e@w2 & e@w3 \\
\hline Pier 1 & & & & $\mathbf{6 0 . 0}$ & $\mathbf{1 0 . 5}$ & $\mathbf{8 0 . 0}$ \\
\hline Pier 2 & $\mathbf{4 . 0}$ & & & $\mathbf{5 5 . 0}$ & $\mathbf{1 1 . 0}$ & $\mathbf{1 0 . 0}$ \\
\hline Pier 3 & $\mathbf{3 . 5}$ & - & - & - & - & - \\
\hline Pier 4 & - & - & - & - & - & - \\
\hline
\end{tabular}

\begin{tabular}{|l|l|l|l|l|}
\hline Level 1 Pier Descr. & \multicolumn{1}{|c|}{1} & \multicolumn{1}{|c|}{2} & \multicolumn{1}{|c|}{3} & \multicolumn{1}{|c|}{4} \\
\hline 86. Location (BF) & ere is & s an & tion as & WW \\
\hline 87. Type & no & exte & the & has a \\
\hline 88. Material & foot- & nsio & abut & con- \\
\hline 89. Shape & ing & n to & ment & crete \\
\hline 90. Inclined? & on & the & wall. & foot- \\
\hline 91. Attack $\angle$ (BF) & the & RAB & Like & ing \\
\hline 92. Pushed & DSR & UT & the & expo \\
\hline 93. Length (feet) & - & - & - & - \\
\hline 94. \# of piles & WW. & wall & right & sed \\
\hline 95. Cross-members & The & in & abut & at \\
\hline 96. Scour Condition & USR & the & ment & the \\
\hline 97. Scour depth & WW & same & , the & sur- \\
\hline 98. Exposure depth & form & direc & USR & face. \\
\hline
\end{tabular}

LFP, LTB, LB, MCL, MCM, MCR, RB, RTB, RFP

1- Solid pier, 2- column, 3- bent

1-Wood; 2- concrete; 3- metal; 4- stone

1- Round; 2- Square; 3- Pointed

Y-yes; $N$ - no

$L B$ or $R B$

0- none; 1- laterals; 2- diagonals; 3- both

0- not evident; 1- evident (comment);

2- footing exposed; 3- piling exposed;

4- undermined footing; 5- settled; 6- failed 
99. Pier comments (eg. undermined penetration, protection and protection extent, unusual scour processes, etc.):

There is some stone fill along and immediately upstream of the USRWW.

The USLWW is exposed for four feet (horizonally) from the left abutment. The remaining length of the USLWW furthest from the bridge is covered with road fill and channel material. The DSLWW also is exposed for four feet (horizontally) from the left abutment. Like the USLWW, the remaining length furthest from the bridge is covered with stone fill.

$\mathbf{N}$

$-$

100.

\section{E. Downstream Channel Assessment}

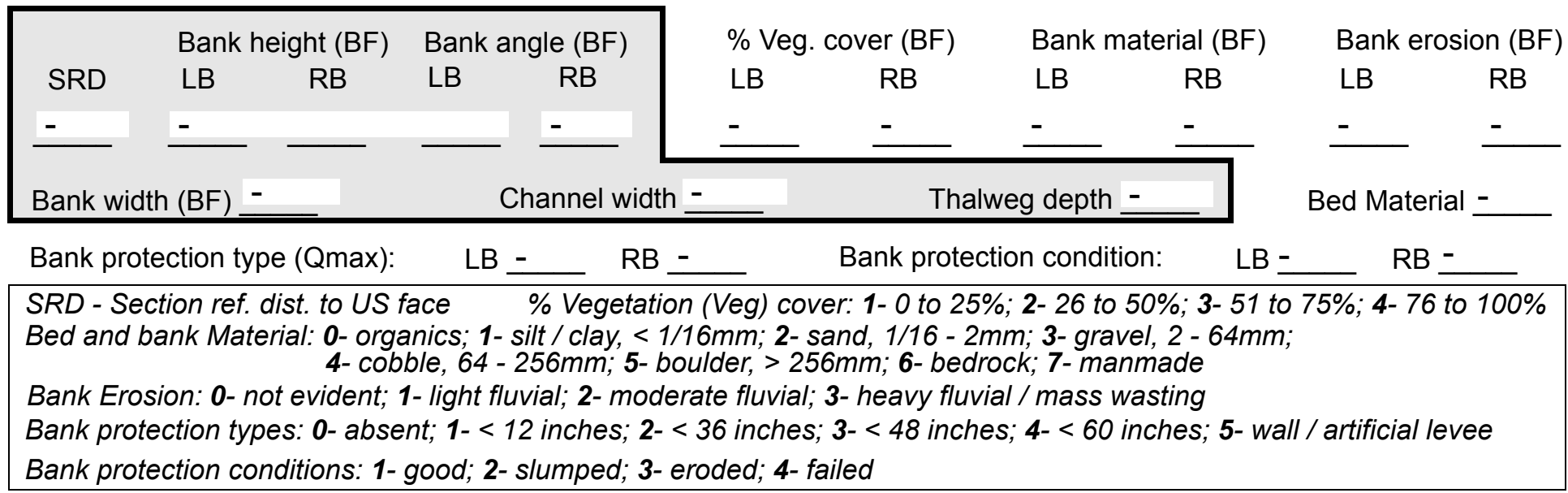

Comments (eg. bank material variation, minor inflows, protection extent, etc.):

$-$

-

$-$

-

$-$

-

-

-

-

101. Is a drop structure present? _ ( $Y$ or $N$, if $N$ type ctrl-n ds) 102. Distance: ___ feet
103. Drop: - feet
104. Structure material:
(1- steel sheet pile; 2- wood pile; 3- concrete; 4- other)

105. Drop structure comments (eg. downstream scour depth): 
106. Point/Side bar present? (Y or $N$. if $N$ type ctrl-n pb)Mid-bar distance:

Mid-bar width: -

Point bar extent: feet -

(US, UB, DS) to feet (US, UB, DS) positioned $\%$ LB to $\% R B$ Material:

Point or side bar comments (Circle Point or Side; note additional bars, material variation, status, etc.):

\section{NO PIERS}

Is a cut-bank present? ( $Y$ or if $N$ type ctrl- $n$ cb) Where? (LB or $R B)$

Mid-bank distance:

Cut bank extent: feet (US, UB, DS) to feet (US, UB, DS)

Bank damage: (1- eroded and/or creep; 2- slip failure; 3- block failure)

Cut bank comments (eg. additional cut banks, protection condition, etc.):

\section{3}

1

213

\section{Is channel scour present? 7 (Y or if $N$ type ctrl-n cs) Mid-scour distance: 2}

Scour dimensions: Length 1 Width 3452 Depth: 2

Positioned $\underline{\mathbf{5}}$ \%LB to $\underline{\mathbf{2}} \%$ RB

Scour comments (eg. additional scour areas, local scouring process, etc.):

1

The right bank protection is stone fill extending from 35 feet DS to 100 feet DS. There is a stone dry masonry wall from 10 feet DS to 35 feet DS.

The left bank is protected along its base only from 15 feet DS to 60 feet DS.

Are there major confluences? Th ( $Y$ or if $N$ type ctrl-n $m c)$

How many?

Confluence 1: Distance mate Enters on rial $(L B$ or $R B)$

Type of (1- perennial; 2- ephemeral)

Confluence 2: Distance the

Enters on DSL $(L B$ or RB)

Type $\underline{B}$ is (1- perennial; 2- ephemeral)

Confluence comments (eg. confluence name):

unclear due to the stone fill and stone wall covering. But is probably much like that of the LBDS.

\section{F. Geomorphic Channel Assessment}

1- Constructed

2- Stable

3- Aggraded

4- Degraded

5- Laterally unstable

6- Vertically and laterally unstable 
108. Evolution comments (Channel evolution not considering bridge effects; See HEC-20, Figure 1 for geomorphic descriptors):

N

$-$

NO DROP STRUCTURE 


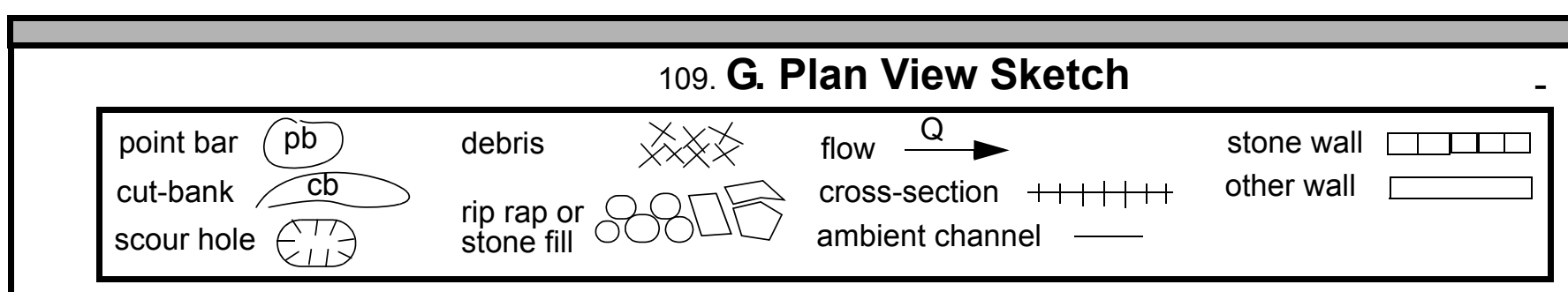


APPENDIX F:

SCOUR COMPUTATIONS 
SCOUR COMPUTATIONS

\begin{tabular}{|c|c|c|c|}
\hline Structure Number: SHEFTH00410018 & & Town: & SHEFFIELD \\
\hline Road Number: $\quad$ TH 41 & & County: & CALEDONIA \\
\hline Stream: MILLERS RUN & & & \\
\hline Initials ECW & Checked: & RLB & \\
\hline alysis of contraction scour, live & ed or $\mathrm{cl} \epsilon$ & ear wat & \\
\hline $\begin{array}{l}\text { Critical Velocity of Bed Material } \\
\text { VC=11.21*y1^0.1667*D50^0.33 with S } \\
\text { (Richardson and others, 1995, p. } 2\end{array}$ & $\begin{array}{l}\text { converted } \\
=2.65 \\
\text { eq. } 16)\end{array}$ & to Engl & sh units) \\
\hline Approach Section & & & \\
\hline Characteristic & $100 \mathrm{yr}$ & $500 \mathrm{yr}$ & other $\mathrm{Q}$ \\
\hline Total discharge, cfs & 2400 & 2950 & 1490 \\
\hline Main Channel Area, ft2 & 341 & 357 & 286 \\
\hline Left overbank area, ft2 & 464 & 503 & 332 \\
\hline Right overbank area, ft2 & 14 & 28 & 1 \\
\hline Top width main channel, ft & 40 & 40 & 40 \\
\hline Top width L overbank, ft & 100 & 101 & 84 \\
\hline Top width $\mathrm{R}$ overbank, ft & 19 & 65 & 3 \\
\hline D50 of channel, ft & 0.167 & 0.167 & 0.167 \\
\hline D50 left overbank, ft & -- & -- & -- \\
\hline D50 right overbank, ft & -- & -- & -- \\
\hline Y1, average depth, MC, ft & 8.5 & 8.9 & 7.2 \\
\hline Y1, average depth, LOB, ft & 4.6 & 5.0 & 4.0 \\
\hline Y1, average depth, ROB, ft & 0.7 & 0.4 & 0.3 \\
\hline Total conveyance, approach & 82778 & 91740 & 57072 \\
\hline Conveyance, main channel & 39892 & 42954 & 29800 \\
\hline Conveyance, LOB & 42592 & 48346 & 27264 \\
\hline Conveyance, ROB & 294 & 440 & 8 \\
\hline Percent discrepancy, conveyance & 0.0000 & 0.0000 & 0.0000 \\
\hline Qm, discharge, MC, cfs & 1156.6 & 1381.2 & 778.0 \\
\hline Ql, discharge, LOB, cfs & 1234.9 & 1554.6 & 711.8 \\
\hline Qr, discharge, ROB, cfs & 8.5 & 14.1 & 0.2 \\
\hline Vm, mean velocity $M C$, ft/s & 3.4 & 3.9 & 2.7 \\
\hline Vl, mean velocity, LOB, ft/s & 2.7 & 3.1 & 2.1 \\
\hline Vr, mean velocity, ROB, ft/s & 0.6 & 0.5 & 0.2 \\
\hline Vc-m, crit. velocity, MC, ft/s & 8.8 & 8.9 & 8.6 \\
\hline VC-1, crit. velocity, LOB, ft/s & ERR & ERR & ERR \\
\hline Vc-r, crit. velocity, ROB, ft/s & $\mathrm{ERR}$ & ERR & ERR \\
\hline Results & & & \\
\hline Live-bed(1) or Clear-Water(0) Cont & action $\mathrm{Scc}$ & our? & \\
\hline Main Channel & 0 & 0 & 0 \\
\hline Left Overbank & $\mathrm{N} / \mathrm{A}$ & $\mathrm{N} / \mathrm{A}$ & $\mathrm{N} / \mathrm{A}$ \\
\hline Right Overbank & $\mathrm{N} / \mathrm{A}$ & $\mathrm{N} / \mathrm{A}$ & $\mathrm{N} / \mathrm{A}$ \\
\hline
\end{tabular}


Clear water Contraction Scour in MAIN CHANNEL

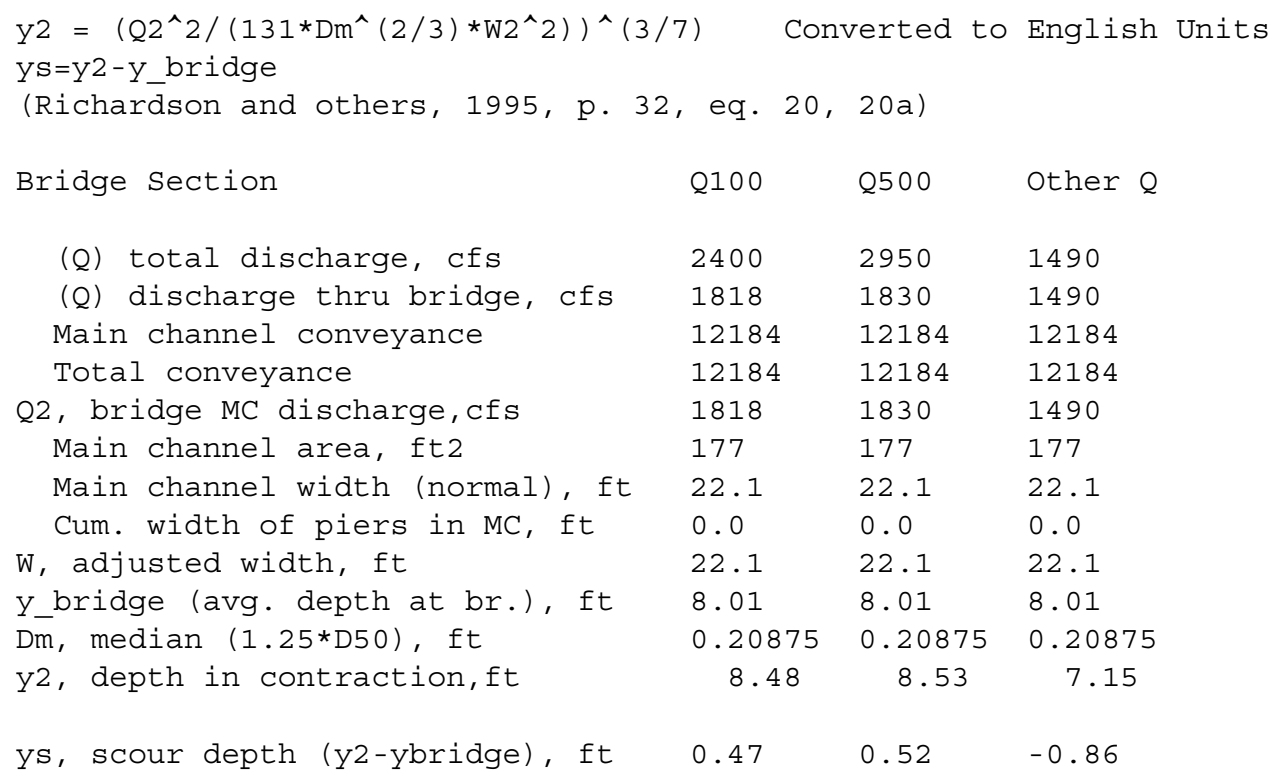

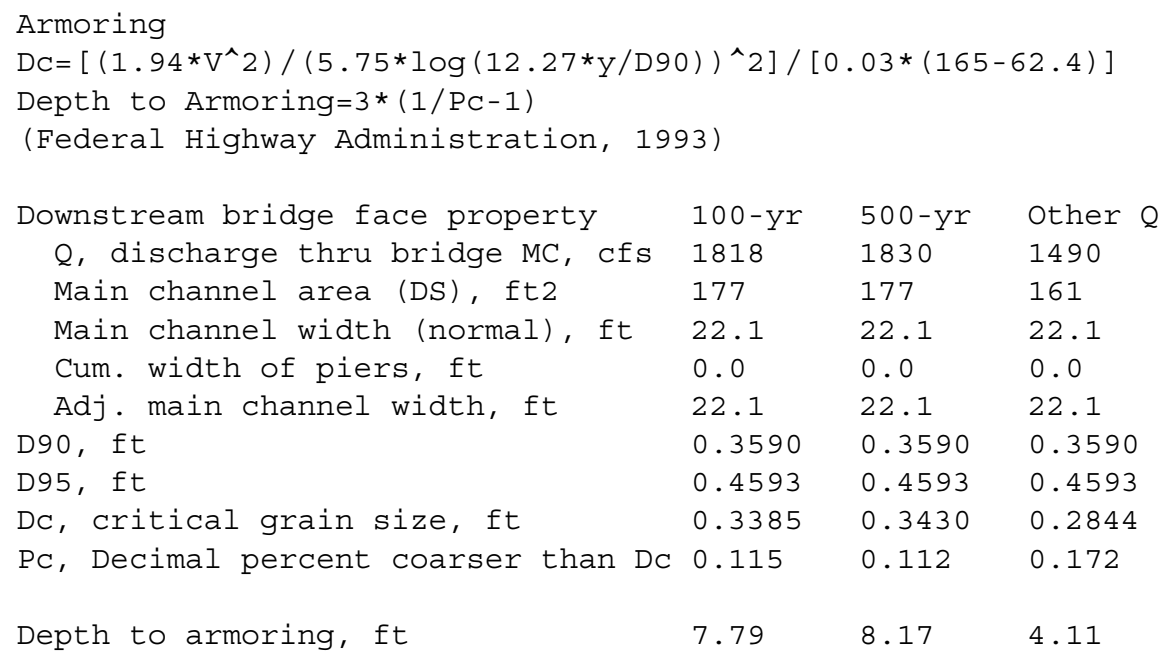




\begin{tabular}{|c|c|c|c|c|}
\hline $\begin{array}{l}\text { Chang pressure flow equation } \\
\text { Cq=1/Cf*CC Cf=1.5*Fr^0.43 (<=1) } \\
\text { Umbrell pressure flow equation } \\
\text { (Hb+Ys)/ya=1.1021*[(1-w/ya)* (Va/VC) } \\
\text { (Richardson and other, 1995, p. } 144\end{array}$ & $\begin{array}{l}\mathrm{Hb}+\mathrm{Ys}=\mathrm{C} \\
\mathrm{CC}=\mathrm{SQRT} \\
]^{\wedge} 0.6031 \\
-146)\end{array}$ & $\begin{array}{l}\text { * qbr/Vc } \\
0.10(\mathrm{Hb} /\end{array}$ & $(y a-w)-0.56)]+0.79$ & $(<=1)$ \\
\hline & Q100 & Q500 & OtherQ & \\
\hline Q, total, cfs & 2400 & 2950 & 1490 & \\
\hline Q, thru bridge $M C$, cfs & 1818 & 1830 & 1490 & \\
\hline Vc, critical velocity, ft/s & 8.82 & 8.89 & 8.57 & \\
\hline Va, velocity MC approach, ft/s & 3.39 & 3.87 & 2.72 & \\
\hline Main channel width (normal), ft & 22.1 & 22.1 & 22.1 & \\
\hline Cum. width of piers in MC, ft & 0.0 & 0.0 & 0.0 & \\
\hline W, adjusted width, ft & 22.1 & 22.1 & 22.1 & \\
\hline qbr, unit discharge, ft2/s & 82.3 & 82.8 & 67.4 & \\
\hline Area of full opening, ft2 & 177.0 & 177.0 & 177.0 & \\
\hline $\mathrm{Hb}$, depth of full opening, ft & 8.01 & 8.01 & 8.01 & \\
\hline Fr, Froude number, bridge MC & 0.64 & 0.65 & 0.52 & \\
\hline Cf, Fr correction factor $(<=1.0)$ & 1.00 & 1.00 & 1.00 & \\
\hline **Area at downstream face, ft 2 & $\mathrm{~N} / \mathrm{A}$ & $\mathrm{N} / \mathrm{A}$ & 161 & \\
\hline **Hb, depth at downstream face, ft & $\mathrm{N} / \mathrm{A}$ & $\mathrm{N} / \mathrm{A}$ & 7.29 & \\
\hline **Fr, Froude number at DS face & $\mathrm{ERR}$ & ERR & 0.60 & \\
\hline$* * \mathrm{Cf}$, for downstream face $(<=1.0)$ & $\mathrm{N} / \mathrm{A}$ & $\mathrm{N} / \mathrm{A}$ & 1.00 & \\
\hline Elevation of Low steel, ft & 497.76 & 497.76 & 497.76 & \\
\hline Elevation of Bed, ft & 489.75 & 489.75 & 489.75 & \\
\hline Elevation of Approach, ft & 500.75 & 501.14 & 499.37 & \\
\hline Friction loss, approach, ft & 0.1 & 0.13 & 0.07 & \\
\hline Elevation of WS immediately US, ft & 500.65 & 501.01 & 499.30 & \\
\hline ya, depth immediately US, ft & 10.90 & 11.26 & 9.55 & \\
\hline Mean elevation of deck, ft & 499.52 & 499.52 & 499.52 & \\
\hline w, depth of overflow, ft $(>=0)$ & 1.13 & 1.49 & 0.00 & \\
\hline Cc, vert contrac correction $(<=1.0)$ & 0.95 & 0.95 & 0.96 & \\
\hline$* *$ CC, for downstream face $(<=1.0)$ & ERR & ERR & 0.932447 & \\
\hline Ys, scour w/Chang equation, ft & 1.79 & 1.78 & 0.21 & \\
\hline Ys, scour w/Umbrell equation, ft & -1.69 & -1.11 & -2.74 & \\
\hline
\end{tabular}




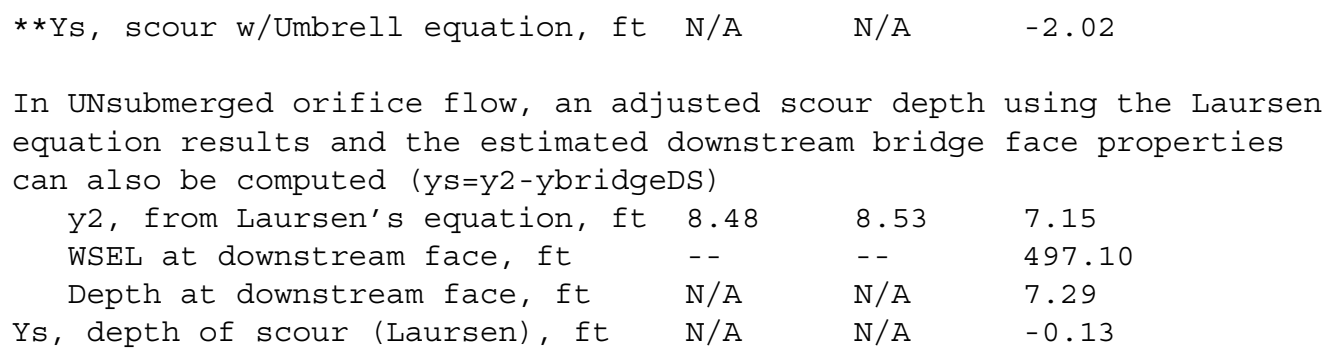

Abutment scour

Froehlich's Abutment Scour

$\mathrm{Ys} / \mathrm{Y} 1=2.27 * \mathrm{~K} 1 * \mathrm{~K} 2 *\left(\mathrm{a}^{\prime} / \mathrm{Y} 1\right)^{\wedge} 0.43 * \mathrm{Fr} 1^{\wedge} 0.61+1$

(Richardson and others, 1995, p. 48, eq. 28)

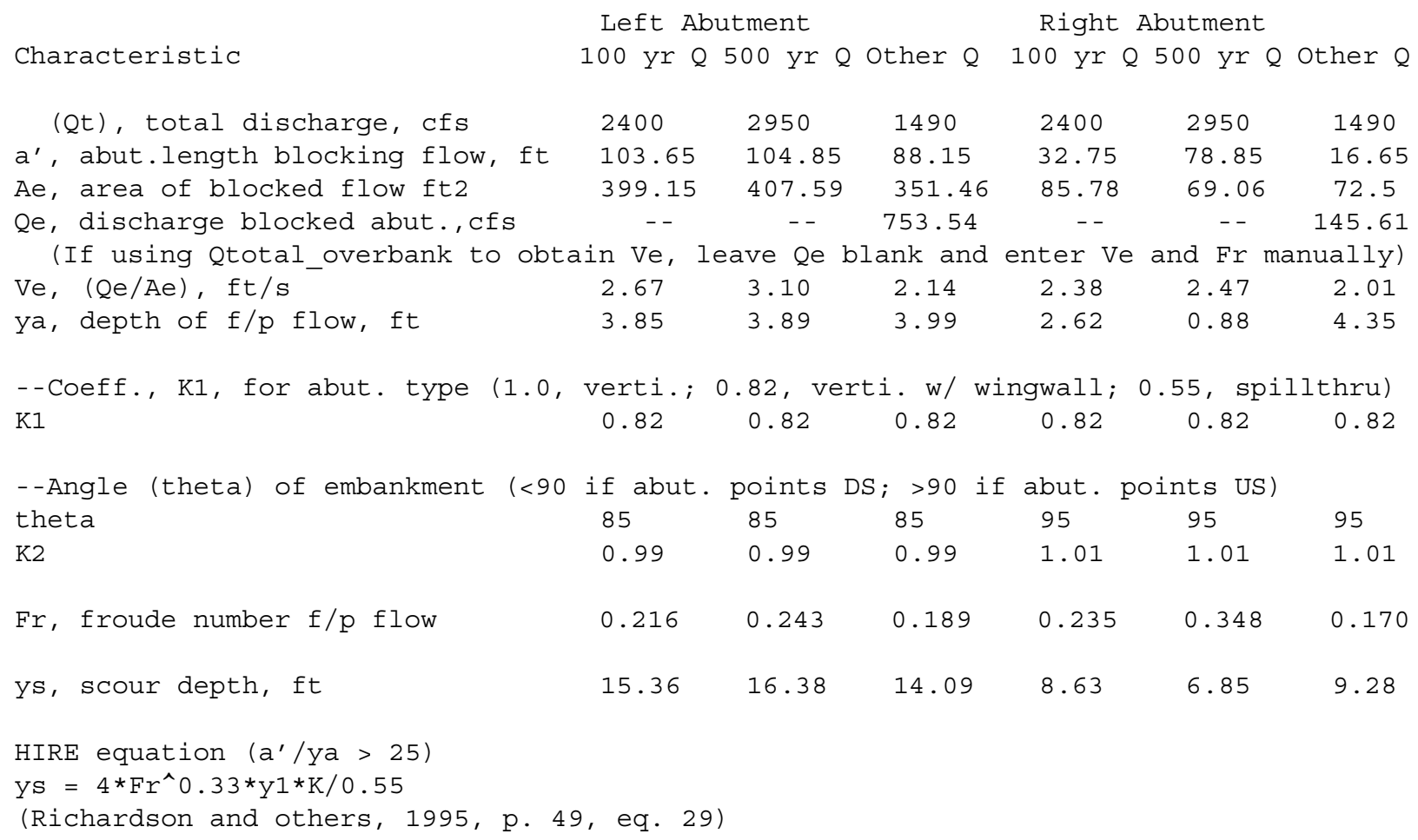




\begin{tabular}{|c|c|c|c|c|c|c|}
\hline$a^{\prime}$ (abut length blocked, ft) & 103.65 & 104.85 & 88.15 & 32.75 & 78.85 & 16.65 \\
\hline y1 (depth f/p flow, ft) & 3.85 & 3.89 & 3.99 & 2.62 & 0.88 & 4.35 \\
\hline$a^{\prime} / y 1$ & 26.92 & 26.97 & 22.11 & 12.50 & 90.03 & 3.82 \\
\hline Skew correction (p. 49, fig. 16) & 0.98 & 0.98 & 0.98 & 1.01 & 1.01 & 1.01 \\
\hline Froude no. f/p flow & 0.22 & 0.24 & 0.19 & 0.24 & 0.35 & 0.17 \\
\hline Ys w/ corr. factor $\mathrm{K} 1 / 0.55$ : & & & & & & \\
\hline vertical w/ $w^{\prime} \mathrm{s}$ & $\begin{array}{l}16.60 \\
13.61\end{array}$ & $\begin{array}{l}17.42 \\
14.29\end{array}$ & $\begin{array}{l}E R R \\
\text { ERR }\end{array}$ & $\begin{array}{l}E R R \\
\text { ERR }\end{array}$ & $\begin{array}{l}4.55 \\
3.73\end{array}$ & $\begin{array}{l}\text { ERR } \\
\text { FRR }\end{array}$ \\
\hline spill-through & 9.13 & 9.58 & ERR & ERR & 2.50 & ERR \\
\hline Abutment riprap Sizing & & & & & & \\
\hline Isbash Relationship & & & & & & \\
\hline $\begin{array}{l}\mathrm{D} 50=\mathrm{Y} * \mathrm{~K} * \mathrm{Fr}{ }^{\wedge} 2 /(\mathrm{Ss}-1) \text { and } \mathrm{D} 50=\mathrm{Y} * \mathrm{~K} *( \\
\text { (Richardson and others, 1995, p11 }\end{array}$ & $\begin{array}{l}\wedge 2)^{\wedge} 0.1 \\
\text { eq. } 81\end{array}$ & ( $(\mathrm{Ss}-1)$ & & & & \\
\hline Characteristic & Q100 & Q500 & Other Q & Q100 & Q500 & Other Q \\
\hline Fr, Froude Number & 0.64 & 0.65 & 0.6 & 0.64 & 0.65 & 0.6 \\
\hline y, depth of flow in bridge, ft & 8.01 & 8.01 & 7.29 & 8.01 & 8.01 & 7.29 \\
\hline Median Stone Diameter for riprap & : left & utment & & right & abutment, & ft \\
\hline Fr<=0.8 (vertical abut.) & 2.03 & 2.09 & 1.62 & 2.03 & 2.09 & 1.62 \\
\hline Fr>0.8 (vertical abut.) & ERR & ERR & ERR & ERR & ERR & ERR \\
\hline
\end{tabular}

